TMD DISCUSSION PAPER NO. 85

\begin{tabular}{|c|}
\hline DEVELOPING COUNTRY INTERESTS IN \\
AGRICULTURAL REFORMS UNDER THE WORLD \\
TRADE ORGANIZATION \\
Xinshen Diao \\
International Food Policy Research Institute \\
Terry Roe \\
University of Minnesota \\
Agapi Somwaru \\
USDA/ERS
\end{tabular}

\author{
Trade and Macroeconomics Division \\ International Food Policy Research Institute \\ 2033 K Street, N.W. \\ Washington, D.C. 20006, U.S.A.
}

January 2002

TMD Discussion Papers contain preliminary material and research results, and are circulated prior to a full peer review in order to stimulate discussion and critical comment. It is expected that most Discussion Papers will eventually be published in some other form, and that their content may also be revised. This paper is available at: http://www.cgiar.org/ifpri/divs/tmd/dp.htm 


\title{
DEVELOPING COUNTRY INTERESTS IN AGRICULTURAL REFORMS UNDER THE WORLD TRADE ORGANIZATION
}

\author{
Xinshen Diao, Terry Roe, and Agapi Somwaru*
}

\begin{abstract}
The gains to developing countries from agricultural reform in developed countrie s is found to benefit most, even the net food importers, although the gains vary depending on a country's trade pattern. This results because the agricultural policy of a small number of developed countries cause the major distortions in world markets, and developing countries whose major share of agricultural trade is with the E.U. are impacted quite differently than those trading with the U.S. Even though Japan and Korea maintain high trade barriers, these barriers are found to have small effects on developing countries. The long-run benefits of reform are found to greatly exceed the short-run gains.
\end{abstract}

\footnotetext{
* The paper was presented at ASSA meetings January 4-6, 2002, Atlanta, Georgia. The authors appreciate comments from John Dyck, Praveen Dixit, Demcey Johnson, John Dunmore and the participants of the meetings at the session "Agricultural Policy Reforms in the WTO."
} 


\section{Table of Contents.}

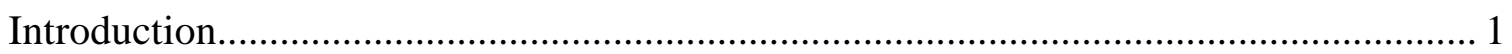

Developing Countries' Agricultural Export Markets Are in the North............................ 2

Distortions in World Agricultural Markets Are Mainly Due to A Few Countries in the

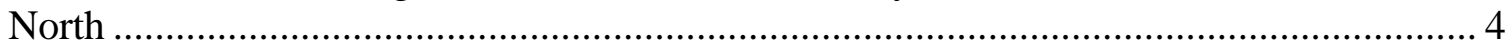

An Open EU Market is in the Common Interest of Most Developing Countries .............. 5

Effects of Reform on Food Security Are Mixed...................................................... 8

Welfare Gains for Developing Countries Are Higher In the Long-run .......................... 10

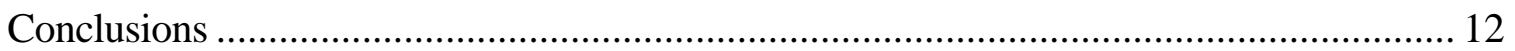

Appendix: Country and Commodity Groups in the Model ...................................... 16

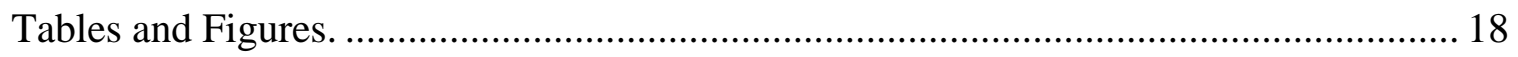

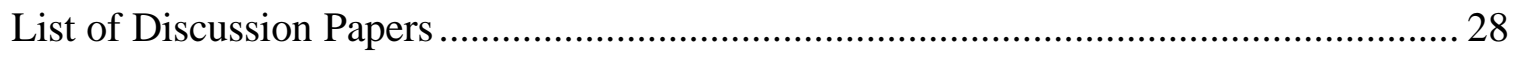




\section{Introduction}

Growth in the number of countries engaged in international trade and the share of world GDP traded show that the new era of globalization is far-reaching. It is shown that the integration of the developing countries into the multilateral trade system has been especially impressive for a group of middle and higher income developing countries in Latin America and Asia (Michalopoulos, 1999). This process was stimulated by lowering barriers to trade in goods, services, and ideas causing many of these countries to benefit, with some doubling their per capita income in a period of less than ten years (Baldwin and Martin, 1999). However, for many others, this process has been much more protracted. This is due to both the slow processes of liberalization of their trade regimes and to the slow relaxation of conditions affecting access to the major markets of their export products. Protection in agriculture by countries in the North is still quite high, remaining a constraint to trade to many countries in the South. Since most developing countries have a disproportionate share of their resources in agriculture, a more open world agricultural market should afford them greater opportunities to increase exports and to participate more actively in the new globalization era. This study focuses on these linkages with emphasis on the cost of agricultural protection in the North to developing countries.

Global negotiations on agriculture were initiated in March 2000. These negotiations are expected to press for the continuation of the reforms initiated during the Uruguay Round, namely reduction of producer export subsidies, increase in import market access, and cuts in domestic farm support. There tend to be diverse and even divergent interests in the new round of World Trade Organization (WTO) negotiations among some countries of the South. These differences arise in part from the concern that liberalization may lead to a rise in food prices with negative consequences for net food importing countries.

This concern may not be well founded, however, because the type of agricultural products that developing countries tend to export (e.g., fruits, vegetables, sugar) are not 
the products that dominate commodity exports from countries of the North; yet it is these categories of commodities for which the North tends to erect trade barriers. Moreover, the pattern of world agricultural trade is such that most countries in Africa tend to trade with Europe while many countries of Latin America and Asia tend to trade with the U.S. The barriers imposed by the U.S. are different from those of the European Union (EU), and consequently trade reform is likely to have quite different impacts on countries in Africa relative to those in Latin America or in Asia. While liberalization may lead to a rise in the price of grains, access to the developed country markets for commodities such as fruits, vegetables, and sugar by countries of the South may more than compensate them for the increase in cost of imported grains. However, the level of compensation is likely to vary by region in the world.

Thus, identifying and measuring the extent of developing countries' gains and losses by region from liberalizing world agricultural markets are important to understanding the nature of their interest in trade reform, as well as to facilitate possible policies to minimize the losses of the adjustment process. For this purpose, we first focus on the data pertaining to North - South and regional agricultural trade. This analysis suggests how reform in the North is likely to have differential impacts on developing countries in different regions. Then, we report the results from a global general equilibrium model in which developed and developing countries are categorized into various subgroups. Based on a global database (the Global Trade Analysis Project [GTAP] database version 5, 2001), we discuss the interests of different developing country subgroups and quantify the potential impacts of a global agricultural liberalization process.

\section{Developing Countries' Agricultural Export Markets Are in the North}

Forty developing country groups are identified in the database. Many countries are themselves "groups." According to the 1998 trade database, among these groups, there are seven for which agricultural exports accounted for more than $40 \%$ of their total exports; nine for which it accounted for 20 to $40 \%$, and seven for which it accounted for 10 to $20 \%$ (figure 1). Most developing countries' agricultural export markets are in the 
North. On average, $65 \%$ of developing countries' total agricultural exports are imported by Northern countries. Figure 2 shows the importance of three of the largest markets in the world - East Asia, represented by Japan and Korea, North America, the U.S. and Canada, and the EU - to the developing countries' agriculture.

There are 20 agricultural and processed food commodity groups in the database. Except for rice, for which a few Asian countries' exports account for $70 \%$ of world rice trade, the North, especially the U.S. and Canada, dominates world grain exports. Exports of non- grain crops, such as vegetables and fruits, cotton, sugar, and vegetable oil, are largely the domain of developing countries (table 1). Excluding intra-EU trade, developing countries account for 60 to $80 \%$ of world exports of these commodities, most of which are exported to the North (table 2). Hence, the agricultural exports of most developing countries do not compete directly with the exports of developed countries. In this case, if most developed countries eliminated their protection of agriculture, exports of developing countries should rise.

Agriculture is still highly protected in many developed countries, especially in Japan and member countries of the EU and the European Free Trade Association (EFTA). The average tariff rate, one indicator of agricultural protection, for bulk agricultural commodities is more than 50\% in Japan, more than 23\% in the EU, and around 100\% for the three members of the EFTA - Norway, Switzerland, and Iceland (ERS/USDA, 2001). Figure 3 presents the developing countries' market shares in the total agricultural imports of Japan and Korea, North America, and the EU. Compared to the other two groups, the developing countries' export shares are consistently small for most commodities in the EU (expect for cotton). The high protection level provides a partial explanation. For example, the tariff rate on vegetables and fruits in the EU market is twice the level as that in Japan and Korea, and seven times higher than that in the North America (ERS/USDA, 2001). At the same time, developing countries' exports accounted for fewer than $30 \%$ of EU's imports of vegetables and fruits, but accounted for $45 \%$ and $68 \%$ in the East Asian (Japan and Korea), and North American markets, respectively. 
The low share of developing countries' agricultural exports in the EU market suggests that barriers to trade are the cause. Theory suggests that the broad patterns of trade among "North" countries can be mainly attributed to product differentiation, while trade between "North" and "South" can be attributed to differences in factor composition. Most developed countries are at an almost equivalent stage of development, share a similar composition of factor endowments, and consequently trade with each other mainly in differentiated products (see Helpman, 1998, for detailed analysis of trading patterns). On the other hand, in contrast to countries of the "North," most developing countries are relatively capitalscarce. Their exports are more likely to embody the services of labor or other natural endowments, and their imports are more likely to embody capital from the "North." Thus, we should expect to observe more intra-North trade in manufacturing and services, and more North-South trade in agriculture. We observe that intra-EU trade accounted for $59 \%$ of EU total non-agricultural exports. However, we also observe that the ratio of intra-EU trade in agriculture over EU total agricultural imports is higher than the ratio in non-agriculture, accounting for $72 \%$ of EU agricultural imports.

Thus agricultural protection policies in the EU appear to block developing countries' opportunities for entering the EU. The EU is the largest market in world agricultural trade, so its agricultural policies have important effects on developing countries. If $10 \%$ of intra-EU trade in agriculture were replaced by trade with the South, then the South's total agricultural exports would rise by $9 \%$.

\section{Distortions in World Agricultural Markets Are Mainly Due to A Few Countries in the North}

As measured by the world price effects, we find, not surprisingly, that policies pursued by a small number of countries in the North cause most of the distortions in world agricultural markets. Using the Agricultural Market Access Database (ERS/USDA, 2001), together with the GTAP database version 5, our model results suggest that eliminating agricultural tariff equivalents, domestic support, and export subsidies worldwide would cause agricultural prices to rise by about $12 \%$. This result is 
obtained from a static analysis, without accounting for investment responses to price changes or the adoption and development of new technologies that increased price incentives would likely stimulate. The decomposition of the increase in world prices by developed - developing country-groups shows that agricultural liberalization in the developed countries accounts for about $80 \%$ of the rise in world agricultural prices. Of this $80 \%$, the EU and EFTA account for $50 \%$ of world price distortions, while Japan and Korea, and the North America together account for almost the remaining half.

Three reasons help explain why a small member of countries in the North contribute most to the distortion in world agricultural prices. First, as importers, all of these countries are major players in world agricultural markets. In 1998, Japan and Korea imported $12 \%$ of all agricultural goods traded in the world; the U.S. and Canada imported another $12 \%$, and $42 \%$ for EU and EFTA. Second, most of these countries either impose high import tariffs on a few agricultural commodities, such as the U.S. on sugar, or protect many of their agricultural sectors, as in the case of Japan and Korea, and the EU and EFTA. Eliminating import tariffs should increase import demand while domestic supply would contract in these developed countries. Third, most of the developed countries employ, in various forms, domestic support policies, some of which encourage increased production. In the case of the EU and EFTA, exports of major agricultural goods are also subsidized. Reducing domestic support in these countries should further

decrease farm income, or more precisely, lower the returns to agriculture's sector-specific resources such as land, farm structures, machinery, and owner-operator labor. Together, these forces should place considerable upward pressures on world agricultural prices.

\section{An Open EU Market is in the Common Interest of Most Developing Countries}

Since world agricultural markets are dominated by a small group of developed countries, agricultural liberalization among these countries will create export opportunities for a relatively large number of developing countries. However, this generalization hides important regional linkages. For many of the developing countries, export markets are actually concentrated in a few countries in the North. This is due both 
to geographic proximity and historical linkages, and to regional integration arrangements. For developing countries located in Eastern Europe, the Middle East, Africa, and some in South America, the EU is the largest agricultural export market. The U.S. and Canada are the largest markets for countries in Central and South America, as well as for some countries in Asia. Japan and Korea are the largest markets for neighboring countries in Asia (figure 2). Thus, for many developing countries, the benefits of a liberalized world agricultural market are likely to be regionally differentiated.

We use the change in developing countries' total agricultural exports to illustrate this linkage. Figure 4 presents the possible increase in agricultural exports of developing country groups after fully liberalizing world agriculture. Overall, the results suggest that among the 40 developing countries or groups included in the database (with the exception of only five countries--Malaysia, Viet Nam, Bangladesh, Sri Lanka, and Zimbabwe) the major increase in their agricultural exports is a result of agricultural liberalization in Japan and Korea, the North America, and the EU and EFTA. For 27 of 35 country groups, $50 \%$ or more of the increase in their agricultural exports is due to liberalizing EU agriculture. For two Asian countries (China and Thailand), 50\% of their increase in agricultural exports is due to liberalizing Japanese and Korean agriculture. For the case of two Latin American countries (Mexico and Colombia) more than 50\% of their increase in agricultural exports is due to liberalizing U.S. and Canadian agriculture. These results imply that some countries in the North are far more important to some groups of developing countries than are other Northern countries. In sum, the results suggest that the majority of developing countries share a common interest in calling for a more open EU agricultural market, while a more open Japanese, Korean and U.S. market is in the interest of a smaller group of countries located in Asia and in the Western Hemisphere.

While Japan and Korea are well known for their high agricultural import barriers, a closer look suggests that liberalization in these two countries does not generate large export opportunities for many developing countries. The scale of the Japanese and Korean markets is simply small relative to the U.S. and EU's agricultural markets (figure 2). More importantly, many of this region's import-restricted goods, such as grain and 
livestock products, are goods for which many developing countries do not hold a decisive comparative advantage. Developing countries in total only accounted for $15 \%$ of world wheat exports (and more than half of that share is taken by Argentina). Even though Japan and Korea account for about $11 \%$ of world wheat imports, only $3 \%$ of wheat imports by Japan and Korea originate from developing countries. Similarly, Japan and Korea import more than $27 \%$ of the world's trade in meat and meat products, and only $17 \%$ of these imports originate from developing countries. The developing countries' largest export market share is in vegetables, fruits, and other cash crops (figure 3), commodities for which Japan and Korea's tariff barriers are relatively low. Thus, with the exception of rice, for which only a few Asian countries hold a decisive comparative advantage, gains to the developing countries from trade liberalization in this region are small. However, we should point out that trade in vegetables and fruits is also blocked by many non-tariff barriers, such as phytosanitary barriers, quotas, and voluntary export restraint agreements. Such barriers do not show up in the database we use for the study. Developing country exports are almost surely affected disproportionately by these barriers. If all trade barriers were represented and were removed in the model, developing countries' exports to the North would increase even more.

We also notice that for some developing countries, such as Uganda or Malawi, the increase in total agricultural exports after global agricultural reforms is quite small. One major reason for this outcome is that in the database many non-grain crops are placed in broad categories (called, e.g., vegetables and fruits, or the aggregate "other crops") in which individual developing countries are often net exporters for a narrow subgroup of these commodities. World trade for a specific commodity may not rise or even decline if the current trade barriers imposed by importing countries on this commodity are low. For this reason, some developing countries that specialize in the export of one or a few products in this category, such as tobacco leaf or coffee beans, may not benefit from liberalizing world agricultural markets. If trade liberalization causes these countries' terms of trade to deteriorate, it is possible for their exports to decline while import costs rise, thus lowering their total welfare. 


\section{Effects of Reform on Food Security Are Mixed}

A more open world agricultural market would surely increase export opportunities among developing countries, but as importers of food grains and meats, some of these countries would more likely experience a rise in food prices. Many of the net food importing countries are poor and among the less developed, so that food expenditures account for a large share of household budgets. Consequently, high priced food imports caused by agricultural liberalization may hinder food security. For these reasons, some developing countries have expressed concern that agricultural trade liberalization may worsen their prospects for food security.

Among the 40 developing country groups included in the database, 30 countries are net grain importers. There are only four developing countries that are net exporters of wheat and other grain products (excluding rice). For most developing countries, grains and/or meats account for more than $20 \%$ of their total agricultural imports. While there is no universally acceptable definition of food security, using the cluster method, DiazBonilla et al. (2000) identify more than 70 developing countries that can be categorized as food insecure. They used five indicators to gauge a country's food security standing: (1) food production per capita, an indicator of the ability of a country to feed itself, (2) the ratio of total exports to food imports, an indicator of the ability of a country to finance its food imports out of its total export revenues, (3) the ratio of the non-agricultural population to total population, (4) calories per capita, and (5) protein per capita. For food insecure countries, either all or most of these indicators are far below the world average level. Using the Diaz-Bonilla measure, we identify 13 food insecure countries in the GTAP database. Four major indicators used in Diaz-Bonilla et al. for these countries are displayed in table 3, while the shares of grain and meat imports in these countries' total agricultural imports are presented in figure 5.

Grain and meat account for a large portion of imports to food insecure countries. Grain and livestock are also highly protected in Japan, Korea, the EU and EFTA, so that trade in these products faces the highest level of import barriers in comparison to other 
agricultural commodities. Consequently, liberalization will likely cause the world prices of these commodities to rise more than the prices of other commodities, such as vegetables and fruits. Our model's results show that if all forms of domestic support and border protection in agriculture were removed, world grain and livestock product prices would rise more than $10 \%$ and $25 \%$, respectively, implying a significant rise in the cost of imported food for many developing countries.

Using both the data analysis and the results from the model simulations, we calculate (1) the ratios of imports over consumption for grains, meats, and total agricultural goods, (2) the ratios of the value of total exports over the values of imports of grains, meats, and total agricultural goods, and (3) the change in grain, meat, and agricultural production for all the 40 developing country groups in the database. These composite indicators show 35 countries for which the ratios of grain, meat, or total agricultural imports over consumption rise after agriculture is fully liberalized worldwide. Hence, most developing countries are likely to become more dependent on international markets for food.

Among these countries, the ratios of the value of total exports over the values of grain, meat, and total agricultural imports - indicators that capture the ability of a country to finance its food or agricultural imports out of total export revenues - decline post worldwide agricultural liberalization. However, the results show that more than $50 \%$ of these countries also increase their grain, meat, and total agricultural production post reform, indicating that their ability to feed themselves from domestic production actually increases. Change in the first two groups of indicators may indicate a negative effect of world agricultural liberalization on food security, while the last indicator definitely shows a positive effect.

We select some of the indicators for the 13 food insecure countries in the database to gain further insights into the food security issue. The rise in the ratio of grain imports over grain consumption and the decline in the ratio of total exports over agricultural imports are modest for most of the 13 countries (table 4). However, the results show that 
for five countries whose grain imports accounted for more than $10 \%$ of grain consumption, their grain consumption becomes more dependent on imports while in four of them, grain production declines. We also notice that most of these countries are among the poorest countries in the database. It is, thus, possible that the high import costs could cause their food insecurity to increase.

\section{Welfare Gains for Developing Countries Are Higher In the Long-run}

The earlier analysis ignored the effect of reform on saving, investment, and the pattern of growth in a country's capital stock. The analysis of these effects requires assumptions regarding households' willingness to forgo consumption and invest, the functioning of capital markets and international capital flows, as well as the technological spillovers and improvement in total factor productivity that seem to accompany growth in countries' trade. This kind of analysis captures the direction of change in the long run that seems well within the realm of reason.

In addition to the typical growth model specification, a growth factor related to trade is also added, although the effects of this factor are reported separately. This factor is added because numerous studies find an empirically strong and positive linkage either between a country's growth rate and its openness to international trade (Easterly and Levine, 2000; Frankel and Romer, 1999), specifically between growth and trade with more advanced nations (Coe et al., 1997), or between the improvement in a country's total factor productivity and reduction in its barriers to the openness (Parente and Prescott, 2000). In our study, the effect of openness on economic growth is modeled by adding a technological spillover variable to a country's total factor productivity function. This spillover variable is the share of a country's trade over its GDP, i.e., virtually the same variable used in most of the econometric analysis cited above. ${ }^{1}$ The presumption is that following worldwide agricultural trade reforms, trade volumes of developing countries should grow. Growth in trade volume should increase the rate of learning new skills, and improve organizational methods as more advanced product and process

\footnotetext{
${ }^{1}$ Detailed description about the dynamic model used for the study can be found in Diao and Somwaru (2001).
} 
technologies are often embodied in the imports of investment goods from developed countries. This process should increase labor productivity and returns to capital and land, and it should be particularly strong for developing countries in the process of catching up with technologies already in use in more advanced countries. The elasticity in the TFP function is chosen between $0.05 \%-0.8 \%$ for the first four years in the model. That is, if the share of trade over GDP rises by $1 \%$ in a developing country, then the TFP would grow by $0.05 \%-0.8 \%$ in the first four years for this country. After the fourth year, the TFP level becomes constant. With such model setup, the longer-run type of analysis allows for agricultural trade reform to yield broader economy-wide benefits.

First, considering only the investment incentives created by reform (i.e., not taking into account the trade-technological spillover-growth effects), the short-run intertemporal welfare effects are found to be modest, with values almost identical to the static analysis. However, as production and investment adjustments take time, the welfare effect becomes relatively large over time, and the gain is greater for developing countries. While the worldwide measure of welfare gain in the tenth year doubles the gain accrued in the fifth year, the welfare gain for all developing countries, as a group, triples (table 5). Simply stated, the results suggest that the payoff to agricultural trade policy reform takes time, and the increase in benefits for developing countries exceeds that for developed countries.

Next, we factor in the trade-technological spillover-growth effect of policy reform. In this case, the intertemporal welfare gains increase significantly. Given the limits the large model imposes on computational capacity, we only include a few selected developing countries in the dynamic model while all other developing countries are aggregated into large groups. The results suggest that all developing country groups are better off after worldwide agricultural reform. Further, as the volume of trade between developed and developing countries grows, so do the welfare gains experienced by even the poorest of the developing countries (table 5). 
These long-run results may be "optimistic" for the case of some countries. Observation suggests that technological spillovers are uneven, and there are areas untouched by the global changes that have taken place. In particular, countries in South Asia and Sub-Saharan Africa have a far lower share of the world's trade and capital inflows and they remain among the poorest in the world. In the case of these countries, it is possible for the poor people living in remote rural areas to be more marginalized by the process of trade liberalization. To spread the benefit of globalization to them is a major challenge.

\section{Conclusions}

Developing countries have increased their integration into the world economy in the last two decades. This trend has been especially impressive in a group of countries in Latin America and Asia. Most of these countries have doubled their per capita income in a period of less than ten years. However, for many others, especially countries in South Asia and Africa, this process has been much more abstracted and there were only marginal gains from globalization. As most developing countries have a disproportionate share of their resources in agriculture, and the major markets of their exports goods are in the North, a more open world agricultural market should afford them greater opportunities to increase exports and to participate more actively in the new globalization era.

By focusing on the cost of agricultural protection in the North to developing countries, we find that distortions in the world agricultural markets are mainly due to a few countries in the North. Our model results suggest that the current level of world prices for agriculture is about $8 \%$ to $10 \%$ below that if all agricultural tariffs, export subsidies and domestic supports were removed in the North. We also find that an open EU market is in the common interest of most developing countries. This follows because the EU is the largest market for many developing countries' agricultural exports, and the EU agriculture is still highly protected which causes intra-EU agricultural trade to be disproportional high. If $10 \%$ of intra-EU agricultural trade were replaced by imports 
from developing countries, it would create export opportunities equivalent to $9 \%$ of all developing countries' agricultural exports in 1998.

Many developing countries have a comparative advantage in fruits, vegetables, sugar, or other non-grain crops. $60 \%$ to $80 \%$ of South's exports of these goods went to the North markets. Trade in these commodities are not only restricted by tariff barriers, but also by a series of non-tariff barriers, such as phytosanitary, quotas, and voluntary exports restraint agreements. Developing countries' exports are disproportionately affected by these barriers. Unfortunately, such barriers do not show up in the database, and hence, we may underestimate the potential export opportunities for many developing countries if all trade barriers were removed.

We also notice that for some African countries who highly depend on the exports of a narrow group of commodities, such as tobacco leaf and coffee bean, a more liberalized world market may not be able to create more export opportunity for them. For these countries, in order to take advantage of a liberalized world market, it is necessary to diversify their trade structure and build up production and export capacity in nontraditional commodity markets. To achieve this, they will almost surely need help from wealthy countries and international organization as many of them are among the poorest countries in the world.

Many developing countries are net food importing countries. A rise in the prices for grain and meat products due to agricultural liberalization may hinder food security for them. Our model results show that ratio of food imports over domestic total consumption would rise, while the ratio of total exports over food imports - an indicator to capture the ability of a country to finance its food imports out of total export revenuers - also decline for many developing countries. Such results suggest that liberalization will have a negative effect on food security. However, the results also show that more than half of these countries also increase food production post reform, implying that their ability to feed themselves from domestic production actually improves. 
World agricultural trade is also distorted by the trade barriers imposed by developing countries. Moreover, one study shows that protection appears to be greater in lowincome than in middle- and higher- income developing countries (Michalopoulos, 1999). This suggests a considerable range in the type of challenges and opportunities different developing countries will face in the context of future WTO negotiations. However, by taking into account the possible gains to growth due to increase in investment and technological spillovers embodied in trade, our study finds that liberalizing both developing and developed countries' agricultural trade is in the long-run interest of all developing countries. 


\section{References}

Baldwin, R., and P. Martin. "Two Waves of Globalization: Superficial Similarities, Fundamental Differences.” Working paper 6904, National Bureau of Economic Research, 1999.

Coe, D.T., E. Helpman, and A. W. Hoffmaister. "North-South R\&D Spillovers," The Economic Journal 107(1997):134-49.

Diao, X. and A. Somwaru. "A Dynamic Evaluation of the Effects of a Free Trade Area of the Americas - An Intertemporal, Global General Equilibrium Model.” J. Econ. Integration 16(first quarter, 2001):21-47.

Diaz-Bonilla, E., M. Thomas, S. Robinson, and A. Cattaneo. "Food Security and Trade Negotiations in the World Trade Organization: a Cluster Analysis of Country Groups.” TMD Discussion paper No 59, International Food Policy Research Institute, 2000.

Easterly, W., and R. Levine. "It's Not Factor Accumulation: Stylized Facts and Growth Models." Paper presented at the World Bank Conference entitled "What Have We Learned from a Decade of Empirical Research on Growth?" Washington, DC, 2000.

Frankel, J.A., and D. Romer. "Does Trade Cause Growth?" Amer. Econ. Rev. 89(1999):379-99.

Helpman, E. “The Structure of Foreign Trade.” Working paper 6752, National Bureau of Economic Research, 1998.

Michalopoulos, Constantine. "Trade Policy and Market Access Issues for Developing Countries.” Memo, World Bank, September 1999.

Parente, S.L., and E.C. Prescott. Barriers to Riches, Cambridge, MA: MIT Press, 2000.

U.S. Department of Agriculture, Economic Research Service. "Agricultural Policy Reform in the WTO, the Road Ahead." Agricultural Economic Report No. 802, ERS/USDA, 2001. 


\section{Appendix: Country and Commodity Groups in the Model}

Country groups

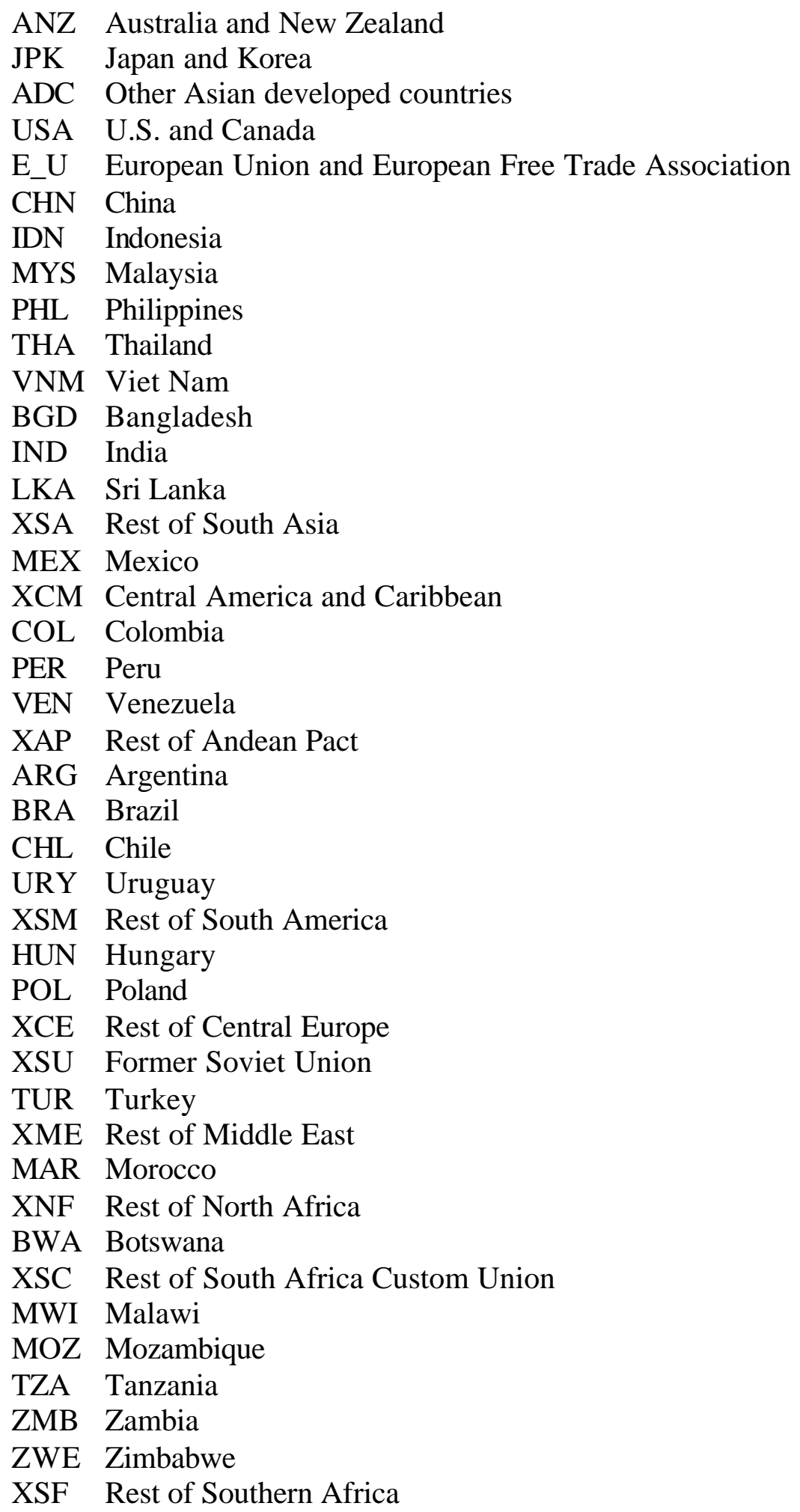


UGA Uganda

XSS Rest of Sub-Saharan Africa

XRW Rest of World

Commodity groups

PDR rice

WHT wheat

GRO other grains

V_F vegetable and fruits

OSD oilseeds

PFB plant based fibers

OCR other crops

CTL bovine cattle, sheep and goats, horses

OAP other animal products

WOL wool and silk-worm cocoons

CMT bovine cattle, sheep and goat meat products

OMT other meat products

VOL vegetable oils and fats

MIL dairy products

SGR sugar

OFD other food products

B_T beverages and tobacco products

NAG all non-agriculture 
Tables and Figures.

Table 1. Share of country's exports in world total exports by commodity, 1998

\begin{tabular}{|c|c|c|c|c|c|c|c|c|c|c|c|c|c|c|c|c|c|c|}
\hline & PDR & WHT & GRO & V_F & OSD & PFB & OCR & CTL & OAP & WOL & CMT & OMT & VOL & MIL & SGR & OFD & B_T & All-Ag \\
\hline$\overline{\text { USA }}$ & 15 & 46 & 50 & 14 & 58 & 28 & 9 & 26 & 21 & 0 & 23 & 18 & 13 & 4 & 2 & 13 & 16 & 17 \\
\hline ANZ & 2 & 13 & 2 & 3 & 1 & 10 & 1 & 10 & 6 & 79 & 22 & 1 & 0 & 13 & 6 & 2 & 2 & 5 \\
\hline JPK & 1 & 0 & 0 & 0 & 0 & 0 & 1 & 0 & 1 & 0 & 0 & 1 & 0 & 0 & 1 & 3 & 2 & 1 \\
\hline $\mathrm{ADC}$ & 0 & 0 & 0 & 0 & 0 & 0 & 1 & 0 & 2 & 0 & 0 & 1 & 2 & 0 & 0 & 2 & 1 & 1 \\
\hline E_U* & 14 & 26 & 23 & 41 & 10 & 5 & 23 & 47 & 40 & 6 & 40 & 58 & 31 & 75 & 29 & 46 & 65 & 42 \\
\hline DCS & 32 & 85 & 75 & 58 & 69 & 44 & 35 & 83 & 70 & 86 & 86 & 79 & 46 & 92 & 37 & 65 & 86 & 66 \\
\hline$\overline{M E X}$ & 0 & 0 & 0 & 5 & 0 & 1 & 3 & 3 & 0 & 0 & 0 & 1 & 0 & 0 & 1 & 1 & 2 & $\overline{1}$ \\
\hline $\mathrm{XCM}$ & 2 & 0 & 0 & 5 & 1 & 0 & 7 & 0 & 0 & 0 & 1 & 0 & 0 & 0 & 14 & 1 & 1 & 2 \\
\hline $\mathrm{COL}$ & 0 & 0 & 0 & 1 & 0 & 0 & 7 & 0 & 0 & 0 & 0 & 0 & 0 & 0 & 2 & 0 & 0 & 1 \\
\hline PER & 0 & 0 & 0 & 0 & 0 & 0 & 1 & 0 & 0 & 0 & 0 & 0 & 0 & 0 & 0 & 1 & 0 & 0 \\
\hline VEN & 0 & 0 & 0 & 0 & 0 & 0 & 0 & 0 & 0 & 0 & 0 & 0 & 0 & 0 & 0 & 0 & 0 & 0 \\
\hline XAP & 1 & 0 & 0 & 3 & 0 & 1 & 1 & 0 & 0 & 0 & 0 & 0 & 1 & 0 & 0 & 1 & 0 & 1 \\
\hline ARG & 3 & 9 & 10 & 2 & 2 & 3 & 1 & 1 & 1 & 2 & 4 & 1 & 13 & 1 & 1 & 1 & 0 & 3 \\
\hline BRA & 0 & 0 & 0 & 1 & 12 & 0 & 10 & 0 & 1 & 0 & 1 & 5 & 8 & 0 & 15 & 1 & 1 & 3 \\
\hline CHL & 0 & 0 & 0 & 3 & 0 & 0 & 0 & 0 & 0 & 0 & 0 & 0 & 0 & 0 & 0 & 2 & 1 & 1 \\
\hline URY & 4 & 0 & 0 & 0 & 0 & 0 & 0 & 1 & 0 & 1 & 2 & 0 & 0 & 0 & 0 & 0 & 0 & 0 \\
\hline XSM & 1 & 0 & 0 & 0 & 3 & 1 & 0 & 0 & 0 & 0 & 0 & 0 & 0 & 0 & 1 & 0 & 0 & 0 \\
\hline $\mathrm{CHN}$ & 6 & 0 & 7 & 3 & 2 & 0 & 3 & 1 & 10 & 2 & 0 & 4 & 2 & 0 & 1 & 4 & 2 & 3 \\
\hline IDN & 1 & 0 & 0 & 0 & 0 & 0 & 4 & 0 & 1 & 0 & 0 & 0 & 5 & 0 & 0 & 2 & 0 & 1 \\
\hline MYS & 0 & 0 & 0 & 0 & 0 & 0 & 1 & 0 & 2 & 0 & 0 & 0 & 13 & 0 & 0 & 1 & 0 & 1 \\
\hline PHL & 0 & 0 & 0 & 1 & 0 & 0 & 0 & 0 & 0 & 0 & 0 & 0 & 1 & 0 & 1 & 1 & 0 & 0 \\
\hline THA & 18 & 0 & 0 & 1 & 0 & 0 & 1 & 0 & 0 & 0 & 0 & 2 & 0 & 0 & 8 & 4 & 0 & 2 \\
\hline VNM & 5 & 0 & 0 & 0 & 0 & 0 & 2 & 0 & 0 & 0 & 0 & 0 & 0 & 0 & 0 & 1 & 0 & 0 \\
\hline BGD & 0 & 0 & 0 & 0 & 0 & 1 & 0 & 0 & 0 & 0 & 0 & 0 & 0 & 0 & 0 & 0 & 0 & 0 \\
\hline IND & 17 & 0 & 0 & 2 & 2 & 4 & 3 & 0 & 1 & 0 & 1 & 0 & 3 & 0 & 2 & 2 & 0 & 2 \\
\hline LKA & 0 & 0 & 0 & 0 & 0 & 0 & 1 & 0 & 0 & 0 & 0 & 0 & 0 & 0 & 0 & 0 & 0 & 0 \\
\hline XSA & 6 & 0 & 0 & 0 & 0 & 1 & 0 & 0 & 0 & 0 & 0 & 0 & 0 & 0 & 1 & 0 & 0 & 0 \\
\hline HUN & 0 & 1 & 1 & 0 & 1 & 0 & 0 & 2 & 1 & 0 & 0 & 3 & 1 & 0 & 0 & 0 & 0 & 1 \\
\hline POL & 0 & 0 & 0 & 0 & 0 & 0 & 0 & 2 & 1 & 0 & 0 & 2 & 0 & 1 & 2 & 1 & 0 & 1 \\
\hline XCE & 1 & 0 & 0 & 0 & 1 & 0 & 0 & 2 & 1 & 0 & 0 & 1 & 1 & 1 & 1 & 1 & 1 & 1 \\
\hline XSU & 0 & 2 & 2 & 1 & 4 & 21 & 0 & 0 & 4 & 2 & 2 & 1 & 1 & 2 & 2 & 2 & 2 & 2 \\
\hline TUR & 0 & 0 & 0 & 4 & 0 & 1 & 2 & 0 & 1 & 0 & 0 & 0 & 1 & 0 & 0 & 1 & 0 & 1 \\
\hline XME & 0 & 1 & 0 & 2 & 0 & 4 & 1 & 2 & 2 & 1 & 0 & 0 & 0 & 0 & 0 & 1 & 0 & 1 \\
\hline MAR & 0 & 0 & 0 & 1 & 0 & 0 & 0 & 0 & 0 & 0 & 0 & 0 & 0 & 0 & 0 & 1 & 0 & 0 \\
\hline XNF & 1 & 0 & 0 & 1 & 0 & 1 & 0 & 0 & 0 & 1 & 0 & 0 & 1 & 0 & 0 & 0 & 0 & 0 \\
\hline BWA & 0 & 0 & 0 & 0 & 0 & 0 & 0 & 0 & 0 & 0 & 0 & 0 & 0 & 0 & 0 & 0 & 0 & 0 \\
\hline XSC & 0 & 0 & 1 & 2 & 0 & 0 & 0 & 1 & 1 & 2 & 0 & 0 & 0 & 0 & 3 & 1 & 0 & 1 \\
\hline MWI & 0 & 0 & 0 & 0 & 0 & 0 & 1 & 0 & 0 & 0 & 0 & 0 & 0 & 0 & 0 & 0 & 0 & 0 \\
\hline $\mathrm{MOZ}$ & 0 & 0 & 0 & 0 & 0 & 0 & 0 & 0 & 0 & 0 & 0 & 0 & 0 & 0 & 0 & 0 & 0 & 0 \\
\hline TZA & 0 & 0 & 0 & 0 & 0 & 1 & 1 & 0 & 0 & 0 & 0 & 0 & 0 & 0 & 0 & 0 & 0 & 0 \\
\hline $\mathrm{ZMB}$ & 0 & 0 & 0 & 0 & 0 & 0 & 0 & 0 & 0 & 0 & 0 & 0 & 0 & 0 & 0 & 0 & 0 & 0 \\
\hline ZWE & 0 & 0 & 1 & 0 & 0 & 1 & 2 & 0 & 0 & 0 & 0 & 0 & 0 & 0 & 1 & 0 & 0 & 0 \\
\hline XSF & 0 & 0 & 0 & 0 & 0 & 0 & 0 & 0 & 0 & 0 & 0 & 0 & 0 & 0 & 3 & 0 & 0 & 0 \\
\hline UGA & 0 & 0 & 0 & 0 & 0 & 0 & 1 & 0 & 0 & 0 & 0 & 0 & 0 & 0 & 0 & 0 & 0 & 0 \\
\hline XSS & 0 & 0 & 0 & 2 & 1 & 12 & 10 & 0 & 1 & 0 & 0 & 0 & 1 & 0 & 1 & 1 & 0 & 2 \\
\hline XRW & 0 & 0 & 0 & 1 & 1 & 0 & 1 & 0 & 1 & 0 & 0 & 0 & 1 & 0 & 1 & 1 & 1 & 1 \\
\hline$\underline{\text { LDC }}$ & 68 & 15 & 25 & 42 & 31 & 56 & 65 & 17 & 30 & 14 & 14 & 21 & 54 & 8 & 63 & 35 & 14 & 34 \\
\hline
\end{tabular}

* Including intra-EU trade

Source: GTAP data. 
Table 2. Share of exports to developed countries in developing countries' total exports by commodity (1)

\begin{tabular}{|c|c|c|c|c|c|c|c|c|c|c|c|c|c|c|c|c|}
\hline & \multicolumn{4}{|c|}{ Rice } & \multicolumn{4}{|c|}{ Wheat } & \multicolumn{4}{|c|}{ Corn and others } & \multicolumn{4}{|c|}{ Vegetable and fruit } \\
\hline & JPK & USA & E_U & DCS & $\begin{array}{l}\text { JPK } \\
\end{array}$ & & $\bar{E}$ E_U & DCS & JPK & USA & E_U & DCS & JPK & USA & E_U & $\overline{\mathrm{DCS}}$ \\
\hline$\overline{\mathrm{MEX}}$ & $\overline{1}$ & 25 & 2 & 28 & 0 & $\overline{0}$ & 86 & 86 & 5 & 18 & 13 & 38 & 2 & 89 & 4 & $\overline{96}$ \\
\hline $\mathrm{XCM}$ & 3 & 3 & 69 & 77 & 3 & 3 & 6 & 12 & 1 & 2 & 3 & 6 & 0 & 49 & 45 & 94 \\
\hline COL & 15 & 17 & 38 & 75 & 15 & 17 & 40 & 78 & 12 & 15 & 31 & 62 & 0 & 32 & 58 & 91 \\
\hline PER & 4 & 5 & 10 & 20 & 3 & 2 & 4 & d & 22 & 15 & 58 & 96 & 1 & 55 & 35 & 91 \\
\hline VEN & 0 & 0 & 0 & 0 & 15 & 16 & 39 & 75 & 1 & 2 & 3 & 7 & 1 & 35 & 38 & 74 \\
\hline XAP & 0 & 0 & 0 & 1 & 15 & 16 & 36 & 72 & 1 & 0 & 3 & 4 & 6 & 26 & 33 & 66 \\
\hline ARG & 0 & 1 & 0 & 1 & 2 & 0 & 1 & 3 & 12 & 1 & 10 & 25 & 0 & 5 & 43 & 49 \\
\hline BRA & 6 & 7 & 20 & 53 & 0 & 0 & 0 & 0 & 0 & 4 & 1 & 5 & 0 & 47 & 41 & 89 \\
\hline CHL & 10 & 11 & 25 & 49 & 14 & 28 & 34 & 79 & 0 & 75 & 21 & 96 & 3 & 34 & 25 & 69 \\
\hline URY & 1 & 0 & 1 & 1 & 5 & 0 & 7 & 12 & 0 & 0 & 1 & 1 & 0 & 6 & 66 & 73 \\
\hline XSM & 0 & 0 & 60 & 60 & 0 & 0 & 0 & 0 & 0 & 0 & 0 & 0 & 0 & 0 & 96 & 97 \\
\hline $\mathrm{CHN}$ & 12 & 6 & 14 & 36 & 17 & 19 & 41 & 81 & 55 & 0 & 2 & 58 & 31 & 7 & 11 & 66 \\
\hline IDN & 17 & 19 & 41 & 81 & 15 & 17 & 40 & 75 & 25 & 10 & 21 & 61 & 5 & 7 & 23 & 45 \\
\hline MYS & 17 & 19 & 41 & 81 & 0 & 0 & 0 & 0 & 6 & 0 & 0 & 77 & 0 & 1 & 12 & 75 \\
\hline PHL & 16 & 19 & 41 & 81 & 5 & 6 & 43 & 55 & 5 & 2 & 5 & 12 & 51 & 11 & 5 & 77 \\
\hline THA & 5 & 15 & 12 & 58 & 0 & 0 & 10 & 10 & 4 & 12 & 10 & 29 & 6 & 6 & 9 & 69 \\
\hline VNM & 0 & 7 & 1 & 11 & 19 & 27 & 30 & 79 & 10 & 6 & 1 & 90 & 4 & 30 & 16 & 83 \\
\hline BGD & 12 & 15 & 35 & 72 & 0 & 0 & 44 & 44 & 8 & 10 & 24 & 50 & 1 & 1 & 76 & 79 \\
\hline IND & 1 & 5 & 13 & 20 & 10 & 10 & 24 & 47 & 14 & 12 & 28 & 58 & 5 & 27 & 27 & 63 \\
\hline LKA & 14 & 20 & 41 & 82 & 0 & 0 & 0 & 0 & 0 & 0 & 0 & 0 & 2 & 2 & 36 & 43 \\
\hline XSA & 1 & 3 & 4 & 9 & 16 & 18 & 39 & 78 & 14 & 17 & 36 & 72 & 1 & 9 & 19 & 36 \\
\hline HUN & 16 & 18 & 43 & 80 & 0 & 0 & 23 & 23 & 0 & 0 & 21 & 21 & 1 & 1 & 67 & 69 \\
\hline POL & 2 & 3 & 4 & 9 & 0 & 0 & 0 & 0 & 0 & 33 & 7 & 40 & 1 & 1 & 49 & 51 \\
\hline XCE & 13 & 15 & 32 & 63 & 18 & 1 & 6 & 25 & 0 & 0 & 19 & 20 & 5 & 5 & 53 & 65 \\
\hline XSU & 6 & 6 & 13 & 27 & 0 & 0 & 1 & 1 & 0 & 0 & 5 & 6 & 0 & 0 & 11 & 12 \\
\hline TUR & 0 & 1 & 70 & 71 & 12 & 21 & 37 & 72 & 0 & 0 & 5 & 6 & 1 & 4 & 66 & 72 \\
\hline XME & 6 & 9 & 13 & 30 & 0 & 0 & 3 & 4 & 6 & 8 & 13 & 28 & 5 & 4 & 58 & 68 \\
\hline MAR & 16 & 18 & 38 & 75 & 17 & 19 & 41 & 81 & 17 & 19 & 41 & 80 & 2 & 4 & 78 & 84 \\
\hline XNF & 0 & 0 & 0 & 1 & 18 & 21 & 39 & 81 & 17 & 20 & 40 & 81 & 4 & 5 & 62 & 73 \\
\hline BWA & 0 & 1 & 1 & 2 & 19 & 27 & 31 & 80 & 8 & 11 & 13 & 33 & 19 & 27 & 31 & 80 \\
\hline XSC & 1 & 1 & 2 & 3 & 1 & 1 & 2 & 4 & 20 & 0 & 2 & 22 & 4 & 8 & 74 & 90 \\
\hline MWI & 1 & 1 & 1 & 3 & 19 & 27 & 30 & 79 & 15 & 21 & 24 & 62 & 1 & 41 & 20 & 66 \\
\hline MOZ & 19 & 27 & 31 & 80 & 19 & 27 & 30 & 79 & 2 & 3 & 3 & 8 & 0 & 46 & 6 & 53 \\
\hline TZA & 17 & 19 & 41 & 81 & 13 & 14 & 31 & 61 & 17 & 19 & 41 & 81 & 1 & 2 & 9 & 12 \\
\hline ZMB & 13 & 18 & 21 & 54 & 0 & 0 & 0 & 0 & 19 & 27 & 31 & 79 & 1 & 3 & 94 & 99 \\
\hline ZWE & 19 & 27 & 30 & 79 & 0 & 0 & 0 & 0 & 0 & 0 & 2 & 2 & 0 & 1 & 85 & 88 \\
\hline XSF & 18 & 21 & 39 & 81 & 18 & 21 & 39 & 81 & 15 & 18 & 34 & 71 & 15 & 18 & 48 & 84 \\
\hline UGA & 5 & 6 & 12 & 25 & 17 & 18 & 40 & 79 & 2 & 2 & 4 & 7 & 13 & 14 & 48 & 78 \\
\hline XSS & 17 & 22 & 38 & 80 & 3 & 4 & 5 & 12 & 6 & 5 & 17 & 29 & 1 & 1 & 79 & 81 \\
\hline XRW & 14 & 17 & 29 & 69 & 3 & 4 & 34 & 42 & 1 & 2 & 17 & 25 & 9 & 2 & 23 & 38 \\
\hline All & & & & & & & & & & & & & & & & \\
\hline LDCs & 4 & 8 & 13 & 32 & 2 & 1 & 6 & 9 & 21 & 2 & 8 & 33 & 6 & 25 & 38 & 73 \\
\hline
\end{tabular}

Source: GTAP data. 
Table 2. Share of exports to developed countries in developing countries' total exports by commodity (2)

\begin{tabular}{|c|c|c|c|c|c|c|c|c|c|c|c|c|c|c|c|c|}
\hline & \multicolumn{4}{|c|}{ Oilseeds } & \multicolumn{4}{|c|}{ Cotton } & \multicolumn{4}{|c|}{ Other crops } & \multicolumn{4}{|c|}{ Cattle and sheep } \\
\hline & JPK & USA & E_U & DCS & JPK & USA & E_U & DCS & JPK & USA & E_U & DCS & JPK & USA & E_U & $\overline{\mathrm{DCS}}$ \\
\hline$\overline{\mathrm{MEX}}$ & 6 & 61 & 8 & 87 & 19 & 1 & 5 & 31 & 5 & 70 & 23 & 99 & 0 & 100 & 0 & $\overline{100}$ \\
\hline $\mathrm{XCM}$ & 30 & 30 & 14 & 75 & 14 & 5 & 11 & 31 & 7 & 37 & 51 & 96 & 6 & 10 & 15 & 33 \\
\hline COL & 0 & 1 & 1 & 3 & 0 & 1 & 1 & 3 & 10 & 41 & 46 & 97 & 0 & 2 & 0 & 2 \\
\hline PER & 21 & 23 & 45 & 90 & 23 & 0 & 21 & 54 & 13 & 48 & 35 & 96 & 9 & 41 & 23 & 75 \\
\hline VEN & 3 & 14 & 14 & 36 & 10 & 31 & 26 & 70 & 12 & 37 & 49 & 98 & 12 & 15 & 28 & 58 \\
\hline XAP & 11 & 0 & 27 & 37 & 4 & 6 & 14 & 25 & 2 & 57 & 29 & 88 & 2 & 6 & 4 & 13 \\
\hline ARG & 3 & 13 & 60 & 80 & 1 & 0 & 5 & 7 & 1 & 32 & 35 & 70 & 0 & 19 & 8 & 27 \\
\hline BRA & 12 & 3 & 63 & 81 & 0 & 0 & 67 & 67 & 9 & 18 & 57 & 85 & 1 & 30 & 13 & 46 \\
\hline $\mathrm{CHL}$ & 4 & 58 & 6 & 69 & 0 & 0 & 0 & 0 & 13 & 39 & 27 & 81 & 1 & 32 & 5 & 39 \\
\hline URY & 0 & 1 & 49 & 51 & 0 & 0 & 0 & 0 & 0 & 9 & 28 & 39 & 0 & 0 & 1 & 2 \\
\hline XSM & 20 & 0 & 24 & 44 & 0 & 1 & 0 & 1 & 0 & 17 & 54 & 71 & 0 & 0 & 1 & 1 \\
\hline $\mathrm{CHN}$ & 48 & 1 & 25 & 79 & 83 & 0 & 2 & 94 & 30 & 9 & 13 & 72 & 11 & 11 & 25 & 84 \\
\hline IDN & 6 & 6 & 19 & 33 & 12 & 11 & 24 & 49 & 12 & 31 & 27 & 77 & 11 & 12 & 53 & 78 \\
\hline MYS & 0 & 0 & 11 & 36 & 11 & 0 & 0 & 11 & 17 & 7 & 19 & 76 & 13 & 14 & 42 & 81 \\
\hline PHL & 7 & 0 & 79 & 86 & 28 & 28 & 42 & 97 & 8 & 14 & 37 & 66 & 13 & 22 & 44 & 82 \\
\hline THA & 11 & 3 & 6 & 24 & 3 & 0 & 1 & 5 & 29 & 31 & 18 & 82 & 0 & 1 & 1 & 2 \\
\hline VNM & 7 & 0 & 1 & 25 & 0 & 3 & 2 & 94 & 7 & 19 & 39 & 85 & 8 & 12 & 70 & 91 \\
\hline BGD & 0 & 0 & 44 & 45 & 0 & 1 & 4 & 6 & 1 & 1 & 7 & 9 & 12 & 15 & 35 & 72 \\
\hline IND & 5 & 6 & 25 & 43 & 9 & 1 & 11 & 46 & 5 & 18 & 36 & 64 & 14 & 15 & 35 & 69 \\
\hline LKA & 0 & 0 & 1 & 1 & 12 & 13 & 48 & 73 & 11 & 6 & 35 & 56 & 16 & 18 & 40 & 80 \\
\hline XSA & 25 & 22 & 11 & 60 & 8 & 1 & 13 & 47 & 3 & 10 & 18 & 32 & 10 & 12 & 27 & 54 \\
\hline HUN & 0 & 0 & 74 & 74 & 0 & 1 & 66 & 67 & 0 & 3 & 72 & 76 & 0 & 0 & 64 & 65 \\
\hline POL & 0 & 0 & 70 & 70 & 0 & 0 & 65 & 65 & 0 & 2 & 69 & 71 & 0 & 1 & 91 & 92 \\
\hline XCE & 0 & 0 & 67 & 67 & 0 & 0 & 39 & 40 & 3 & 7 & 48 & 59 & 0 & 0 & 51 & 52 \\
\hline XSU & 0 & 0 & 67 & 67 & 10 & 0 & 28 & 38 & 0 & 2 & 11 & 13 & 3 & 4 & 36 & 44 \\
\hline TUR & 4 & 6 & 46 & 56 & 0 & 0 & 65 & 66 & 5 & 44 & 35 & 84 & 10 & 11 & 66 & 89 \\
\hline XME & 0 & 5 & 68 & 74 & 1 & 0 & 42 & 48 & 2 & 11 & 57 & 71 & 2 & 1 & 55 & 58 \\
\hline MAR & 15 & 17 & 44 & 79 & 19 & 18 & 42 & 82 & 10 & 8 & 72 & 91 & 17 & 19 & 42 & 81 \\
\hline XNF & 3 & 4 & 59 & 66 & 23 & 3 & 44 & 71 & 2 & 19 & 49 & 72 & 17 & 20 & 40 & 81 \\
\hline BWA & 1 & 2 & 2 & 5 & 1 & 1 & 1 & 2 & 19 & 27 & 31 & 80 & 0 & 0 & 0 & 0 \\
\hline XSC & 23 & 7 & 40 & 70 & 0 & 0 & 9 & 15 & 4 & 6 & 44 & 65 & 1 & 1 & 2 & 5 \\
\hline MWI & 0 & 0 & 8 & 8 & 0 & 0 & 9 & 9 & 8 & 19 & 48 & 75 & 14 & 20 & 23 & 60 \\
\hline MOZ & 0 & 0 & 83 & 83 & 0 & 0 & 89 & 89 & 2 & 3 & 41 & 46 & 18 & 25 & 35 & 82 \\
\hline TZA & 83 & 3 & 7 & 93 & 1 & 0 & 17 & 35 & 15 & 3 & 60 & 80 & 7 & 8 & 22 & 39 \\
\hline ZMB & 0 & 0 & 0 & 0 & 0 & 0 & 2 & 14 & 3 & 2 & 78 & 86 & 9 & 13 & 68 & 91 \\
\hline ZWE & 0 & 0 & 11 & 11 & 4 & 0 & 45 & 57 & 6 & 3 & 53 & 68 & 4 & 6 & 7 & 17 \\
\hline XSF & 17 & 20 & 40 & 81 & 18 & 21 & 39 & 81 & 18 & 6 & 64 & 96 & 8 & 9 & 73 & 91 \\
\hline UGA & 64 & 1 & 5 & 71 & 6 & 0 & 64 & 70 & 0 & 10 & 73 & 83 & 17 & 18 & 40 & 80 \\
\hline XSS & 39 & 1 & 33 & 74 & 3 & 1 & 31 & 37 & 3 & 10 & 65 & 80 & 6 & 8 & 14 & 30 \\
\hline XRW & 21 & 5 & 24 & 64 & 5 & 6 & 24 & 41 & 11 & 13 & 45 & 84 & 6 & 8 & 61 & 76 \\
\hline All LDCs & 13 & 4 & 50 & 70 & 7 & 1 & 27 & 38 & 9 & 24 & 46 & 83 & 2 & 22 & 38 & 65 \\
\hline
\end{tabular}

Source: GTAP data. 
Table 2. Share of exports to developed countries in developing countries' total exports by commodity (3)

\begin{tabular}{|c|c|c|c|c|c|c|c|c|c|c|c|c|c|c|c|c|}
\hline & \multicolumn{4}{|c|}{ Other animal products } & \multicolumn{4}{|c|}{ Wool } & \multicolumn{4}{|c|}{ Cattle and sheep meat } & \multicolumn{4}{|c|}{ Other meat } \\
\hline & JPK & USA & E_U & $\mathrm{DCS}$ & JPK & USA & E_U & DCS & JPK & USA & E_U & $\mathrm{DCS}$ & JPK & USA & E_U & DCS \\
\hline$\overline{M E X}$ & 6 & 44 & 44 & 94 & 6 & 32 & 14 & 94 & 11 & 38 & 40 & 90 & 81 & 8 & 5 & $\overline{94}$ \\
\hline $\mathrm{XCM}$ & 8 & 7 & 30 & 45 & 16 & 18 & 36 & 74 & 8 & 57 & 6 & 70 & 5 & 11 & 19 & 38 \\
\hline COL & 8 & 34 & 13 & 68 & 17 & 18 & 40 & 80 & 16 & 18 & 39 & 78 & 16 & 17 & 36 & 73 \\
\hline PER & 13 & 21 & 56 & 90 & 0 & 0 & 0 & 0 & 12 & 13 & 29 & 57 & 18 & 4 & 56 & 79 \\
\hline VEN & 1 & 1 & 41 & 44 & 17 & 18 & 40 & 80 & 11 & 12 & 28 & 55 & 1 & 0 & 0 & 2 \\
\hline XAP & 6 & 64 & 13 & 82 & 19 & 10 & 52 & 81 & 41 & 11 & 26 & 81 & 2 & 2 & 20 & 24 \\
\hline ARG & 4 & 50 & 33 & 88 & 0 & 0 & 85 & 85 & 1 & 2 & 53 & 58 & 8 & 36 & 37 & 85 \\
\hline BRA & 15 & 17 & 40 & 73 & 30 & 0 & 3 & 33 & 0 & 0 & 74 & 88 & 13 & 5 & 25 & 55 \\
\hline CHL & 2 & 5 & 38 & 45 & 0 & 2 & 48 & 51 & 3 & 3 & 47 & 55 & 7 & 1 & 33 & 50 \\
\hline URY & 1 & 4 & 61 & 67 & 1 & 11 & 38 & 51 & 0 & 12 & 34 & 48 & 21 & 23 & 38 & 83 \\
\hline XSM & 1 & 3 & 56 & 60 & 19 & 27 & 31 & 80 & 0 & 0 & 14 & 14 & 0 & 15 & 1 & 17 \\
\hline $\mathrm{CHN}$ & 15 & 11 & 27 & 87 & 26 & 7 & 18 & 77 & 7 & 1 & 2 & 42 & 50 & 1 & 7 & 78 \\
\hline IDN & 5 & 5 & 16 & 88 & 17 & 19 & 41 & 81 & 4 & 4 & 9 & 17 & 13 & 7 & 15 & 57 \\
\hline MYS & 2 & 1 & 2 & 98 & 1 & 1 & 2 & 3 & 0 & 0 & 1 & 1 & 6 & 6 & 12 & 61 \\
\hline PHL & 19 & 15 & 31 & 76 & 16 & 19 & 41 & 81 & 15 & 18 & 40 & 77 & 16 & 19 & 40 & 80 \\
\hline THA & 18 & 40 & 7 & 81 & 73 & 0 & 0 & 73 & 17 & 18 & 39 & 78 & 62 & 0 & 26 & 96 \\
\hline VNM & 11 & 6 & 8 & 87 & 0 & 0 & 0 & 55 & 16 & 22 & 25 & 66 & 16 & 1 & 1 & 77 \\
\hline BGD & 20 & 3 & 6 & 30 & 0 & 0 & 0 & 0 & 1 & 1 & 44 & 46 & 0 & 0 & 0 & 0 \\
\hline IND & 47 & 7 & 24 & 80 & 10 & 12 & 51 & 76 & 0 & 0 & 0 & 0 & 13 & 9 & 1 & 23 \\
\hline LKA & 18 & 1 & 61 & 80 & 85 & 0 & 15 & 100 & 16 & 19 & 40 & 80 & 21 & 13 & 33 & 75 \\
\hline XSA & 19 & 4 & 59 & 83 & 2 & 1 & 91 & 95 & 0 & 52 & 3 & 56 & 81 & 0 & 1 & 88 \\
\hline HUN & 7 & 5 & 56 & 72 & 0 & 0 & 70 & 71 & 1 & 1 & 56 & 59 & 1 & 1 & 61 & 63 \\
\hline POL & 11 & 5 & 77 & 93 & 1 & 1 & 98 & 99 & 4 & 1 & 31 & 36 & 1 & 5 & 23 & 29 \\
\hline XCE & 1 & 1 & 61 & 63 & 3 & 3 & 33 & 39 & 6 & 6 & 58 & 71 & 3 & 3 & 27 & 33 \\
\hline XSU & 2 & 1 & 55 & 59 & 0 & 0 & 16 & 16 & 1 & 1 & 2 & 3 & 2 & 1 & 4 & 7 \\
\hline TUR & 1 & 1 & 89 & 92 & 2 & 2 & 81 & 85 & 3 & 3 & 7 & 13 & 2 & 2 & 10 & 74 \\
\hline XME & 0 & 1 & 62 & 63 & 7 & 9 & 38 & 57 & 12 & 15 & 25 & 54 & 5 & 3 & 30 & 40 \\
\hline MAR & 5 & 7 & 81 & 94 & 17 & 19 & 41 & 81 & 13 & 15 & 53 & 84 & 0 & 0 & 100 & 100 \\
\hline XNF & 8 & 10 & 63 & 83 & 16 & 19 & 42 & 80 & 1 & 2 & 56 & 59 & 0 & 0 & 6 & 6 \\
\hline BWA & 0 & 0 & 59 & 59 & 0 & 0 & 0 & 0 & 0 & 0 & 88 & 88 & 3 & 5 & 25 & 33 \\
\hline XSC & 3 & 4 & 72 & 81 & 1 & 2 & 94 & 96 & 4 & 4 & 85 & 94 & 3 & 3 & 46 & 60 \\
\hline MWI & 10 & 0 & 80 & 89 & 0 & 0 & 0 & 0 & 19 & 27 & 31 & 80 & 19 & 27 & 31 & 80 \\
\hline MOZ & 7 & 10 & 14 & 32 & 0 & 0 & 0 & 0 & 0 & 0 & 1 & 1 & 19 & 27 & 31 & 80 \\
\hline TZA & 8 & 8 & 27 & 60 & 0 & 0 & 0 & 0 & 17 & 19 & 41 & 80 & 17 & 18 & 40 & 78 \\
\hline ZMB & 9 & 12 & 32 & 83 & 19 & 27 & 31 & 80 & 10 & 14 & 15 & 40 & 15 & 21 & 37 & 76 \\
\hline ZWE & 13 & 10 & 24 & 82 & 19 & 27 & 31 & 80 & 0 & 0 & 99 & 100 & 0 & 1 & 67 & 68 \\
\hline XSF & 13 & 15 & 38 & 68 & 18 & 21 & 39 & 81 & 18 & 21 & 39 & 81 & 3 & 4 & 89 & 96 \\
\hline UGA & 2 & 1 & 30 & 63 & 0 & 0 & 100 & 100 & 7 & 8 & 74 & 91 & 17 & 18 & 40 & 80 \\
\hline XSS & 5 & 6 & 49 & 67 & 10 & 13 & 47 & 73 & 5 & 6 & 67 & 80 & 11 & 11 & 36 & 61 \\
\hline XRW & 8 & 2 & 47 & 59 & 3 & 2 & 19 & 24 & 9 & 6 & 27 & 43 & 5 & 11 & 22 & 41 \\
\hline All LDCs & 9 & 9 & 39 & 78 & 8 & 5 & 47 & 65 & 2 & 6 & 37 & 49 & 23 & 5 & 26 & 62 \\
\hline
\end{tabular}

Source: GTAP data. 
Table 2. Share of exports to developed countries in developing countries' total exports by commodity (4)

\begin{tabular}{|c|c|c|c|c|c|c|c|c|c|c|c|c|c|c|c|c|}
\hline & \multicolumn{4}{|c|}{ Vegetable oils } & \multicolumn{4}{|c|}{ Dairy products } & \multicolumn{4}{|c|}{ Sugar } & \multicolumn{4}{|c|}{ Other processed food } \\
\hline & JPK & USA & $\overline{E \_U}$ & DCS & JPK & USA & E_U & $\overline{\mathrm{DCS}}$ & JPK & USA & E_U & DCS & JPK & USA & $\overline{E \_U}$ & $\overline{\mathrm{DCS}}$ \\
\hline MEX & 4 & 66 & 10 & 79 & 3 & 17 & 34 & 56 & 0 & 21 & 5 & 27 & 6 & 69 & 9 & 86 \\
\hline XCM & 1 & 5 & 5 & 11 & 3 & 7 & 8 & 19 & 4 & 31 & 17 & 52 & 13 & 37 & 22 & 73 \\
\hline COL & 2 & 5 & 43 & 50 & 8 & 11 & 19 & 40 & 0 & 20 & 1 & 21 & 8 & 37 & 32 & 77 \\
\hline PER & 2 & 2 & 5 & 9 & 11 & 12 & 31 & 57 & 1 & 86 & 1 & 88 & 8 & 8 & 22 & 46 \\
\hline VEN & 4 & 4 & 5 & 13 & 3 & 4 & 8 & 16 & 1 & 84 & 2 & 88 & 2 & 41 & 20 & 64 \\
\hline XAP & 0 & 0 & 0 & 0 & 4 & 5 & 11 & 22 & 4 & 36 & 2 & 42 & 6 & 52 & 24 & 86 \\
\hline ARG & 1 & 0 & 26 & 29 & 0 & 4 & 1 & 5 & 0 & 43 & 1 & 44 & 12 & 18 & 18 & 56 \\
\hline BRA & 6 & 1 & 38 & 47 & 8 & 5 & 16 & 35 & 0 & 9 & 2 & 11 & 15 & 26 & 31 & 76 \\
\hline CHL & 29 & 2 & 8 & 43 & 2 & 2 & 3 & 7 & 5 & 5 & 11 & 21 & 33 & 18 & 15 & 74 \\
\hline URY & 0 & 0 & 20 & 20 & 1 & 2 & 2 & 5 & 16 & 18 & 43 & 82 & 5 & 7 & 15 & 30 \\
\hline XSM & 0 & 1 & 1 & 3 & 8 & 11 & 55 & 76 & 0 & 9 & 82 & 91 & 31 & 37 & 11 & 80 \\
\hline $\mathrm{CHN}$ & 16 & 2 & 7 & 85 & 4 & 3 & 13 & 69 & 4 & 3 & 5 & 21 & 54 & 13 & 9 & 90 \\
\hline IDN & 4 & 9 & 37 & 51 & 2 & 2 & 8 & 14 & 80 & 5 & 10 & 95 & 49 & 20 & 10 & 84 \\
\hline MYS & 9 & 2 & 7 & 27 & 2 & 1 & 2 & 71 & 1 & 0 & 0 & 51 & 13 & 12 & 16 & 78 \\
\hline PHL & 9 & 63 & 15 & 89 & 15 & 14 & 30 & 78 & 9 & 83 & 1 & 97 & 29 & 31 & 17 & 88 \\
\hline THA & 15 & 4 & 9 & 33 & 4 & 5 & 10 & 60 & 43 & 1 & 1 & 47 & 32 & 34 & 16 & 91 \\
\hline VNM & 7 & 0 & 0 & 9 & 0 & 0 & 0 & 8 & 18 & 21 & 9 & 49 & 56 & 10 & 10 & 92 \\
\hline BGD & 9 & 12 & 29 & 58 & 8 & 10 & 25 & 49 & 9 & 11 & 33 & 61 & 15 & 42 & 35 & 95 \\
\hline IND & 15 & 3 & 7 & 36 & 13 & 28 & 30 & 75 & 3 & 5 & 31 & 40 & 32 & 17 & 12 & 64 \\
\hline LKA & 0 & 1 & 43 & 44 & 4 & 5 & 11 & 41 & 0 & 1 & 95 & 99 & 26 & 6 & 16 & 59 \\
\hline XSA & 12 & 3 & 28 & 43 & 11 & 13 & 30 & 58 & 2 & 2 & 73 & 78 & 17 & 11 & 43 & 76 \\
\hline HUN & 0 & 0 & 5 & 5 & 14 & 6 & 13 & 33 & 0 & 0 & 10 & 11 & 1 & 9 & 28 & 38 \\
\hline POL & 1 & 1 & 54 & 56 & 3 & 5 & 27 & 34 & 0 & 3 & 21 & 25 & 3 & 2 & 44 & 49 \\
\hline XCE & 0 & 0 & 14 & 15 & 3 & 6 & 23 & 34 & 0 & 0 & 12 & 12 & 3 & 4 & 26 & 34 \\
\hline XSU & 0 & 1 & 16 & 17 & 10 & 8 & 37 & 55 & 1 & 0 & 3 & 5 & 35 & 11 & 21 & 68 \\
\hline TUR & 0 & 9 & 19 & 28 & 12 & 14 & 35 & 64 & 11 & 12 & 37 & 62 & 2 & 2 & 37 & 42 \\
\hline XME & 9 & 14 & 19 & 48 & 4 & 8 & 7 & 20 & 4 & 5 & 8 & 32 & 7 & 9 & 43 & 67 \\
\hline MAR & 0 & 14 & 82 & 97 & 6 & 6 & 13 & 26 & 13 & 14 & 48 & 78 & 32 & 4 & 50 & 87 \\
\hline XNF & 0 & 2 & 94 & 96 & 16 & 19 & 39 & 77 & 13 & 14 & 46 & 75 & 7 & 9 & 46 & 65 \\
\hline BWA & 0 & 0 & 0 & 0 & 12 & 17 & 19 & 51 & 0 & 0 & 0 & 0 & 1 & 1 & 1 & 2 \\
\hline XSC & 2 & 3 & 16 & 28 & 3 & 4 & 8 & 17 & 15 & 11 & 35 & 61 & 13 & 13 & 41 & 76 \\
\hline MWI & 1 & 2 & 1 & 5 & 19 & 27 & 31 & 80 & 0 & 24 & 76 & 99 & 8 & 16 & 36 & 61 \\
\hline MOZ & 2 & 3 & 3 & 8 & 0 & 0 & 0 & 0 & 0 & 96 & 3 & 99 & 23 & 0 & 71 & 95 \\
\hline TZA & 2 & 2 & 22 & 27 & 17 & 19 & 41 & 81 & 6 & 7 & 79 & 93 & 17 & 10 & 44 & 82 \\
\hline ZMB & 14 & 22 & 32 & 71 & 8 & 11 & 12 & 32 & 0 & 0 & 97 & 97 & 22 & 22 & 27 & 73 \\
\hline ZWE & 1 & 1 & 3 & 5 & 0 & 0 & 1 & 1 & 0 & 11 & 19 & 30 & 1 & 4 & 3 & 11 \\
\hline XSF & 17 & 20 & 37 & 77 & 17 & 20 & 38 & 78 & 0 & 4 & 96 & 100 & 16 & 13 & 64 & 96 \\
\hline UGA & 0 & 0 & 0 & 0 & 17 & 18 & 40 & 80 & 16 & 18 & 42 & 80 & 5 & 10 & 48 & 92 \\
\hline XSS & 1 & 0 & 96 & 97 & 17 & 8 & 12 & 39 & 2 & 20 & 54 & 77 & 13 & 5 & 70 & 91 \\
\hline XRW & 1 & 2 & 72 & 77 & 5 & 8 & 27 & 42 & 8 & 9 & 69 & 86 & 10 & 6 & 49 & 72 \\
\hline All LDCs & 5 & 4 & 23 & 39 & 5 & 7 & 20 & 37 & 8 & 15 & 18 & 42 & 24 & 21 & 24 & 75 \\
\hline
\end{tabular}

Source: GTAP data. 
Table 3. Indicator value used for food security analysis

\begin{tabular}{|c|c|c|c|c|}
\hline & CALCAP $^{(1)}$ & PROTCAP $^{(2)}$ & PRODCAP $^{(3)}$ & IMPEXPOT $^{(4)}$ \\
\hline & (Calories) & (Grams) & (US\$) & $(\%)$ \\
\hline India & 2,400 & 57.4 & 112.5 & 4.8 \\
\hline Philippines & 2,367 & 56.4 & 131.3 & 7.9 \\
\hline Viet Nam & 2,427 & 56.2 & 124.0 & 5.9 \\
\hline Bangladesh & 2,047 & 43.9 & 67.1 & 20.4 \\
\hline Sri Lanka & 2,264 & 50.4 & 73.0 & 12.2 \\
\hline Peru & 2,300 & 58.0 & 120.6 & 14.0 \\
\hline Botswana & 2,208 & 70.6 & 112.7 & 10.0 \\
\hline Malawi & 2,034 & 54.2 & 67.3 & 2.1 \\
\hline Mozambique & 1,727 & 33.1 & 49.5 & 23.0 \\
\hline Tanzania & 2,013 & 48.8 & 91.9 & 21.2 \\
\hline Zambia & 1,964 & 51.3 & 67.3 & 2.1 \\
\hline Zimbabwe & 2,078 & 50.6 & 67.0 & 6.6 \\
\hline Uganda & 2,206 & 50.1 & 118.8 & 6.9 \\
\hline World average & 2,739 & 73.5 & 194.3 & \\
\hline
\end{tabular}

${ }^{(1)}$ Calories per capita per day

(2) Protein consumption per capita per day

${ }^{(3)}$ Food production per capita each year

(4) Ratio of food imports over total exports

Data in (1) - (3) are five-year average between 1993 and 1997 from FAO, while data in (4) are 1998 from GTAP v5.

Source: Diaz-Bonilla et al (2000). 
Table 4. Effects on Food Security for Selected Developing Countries

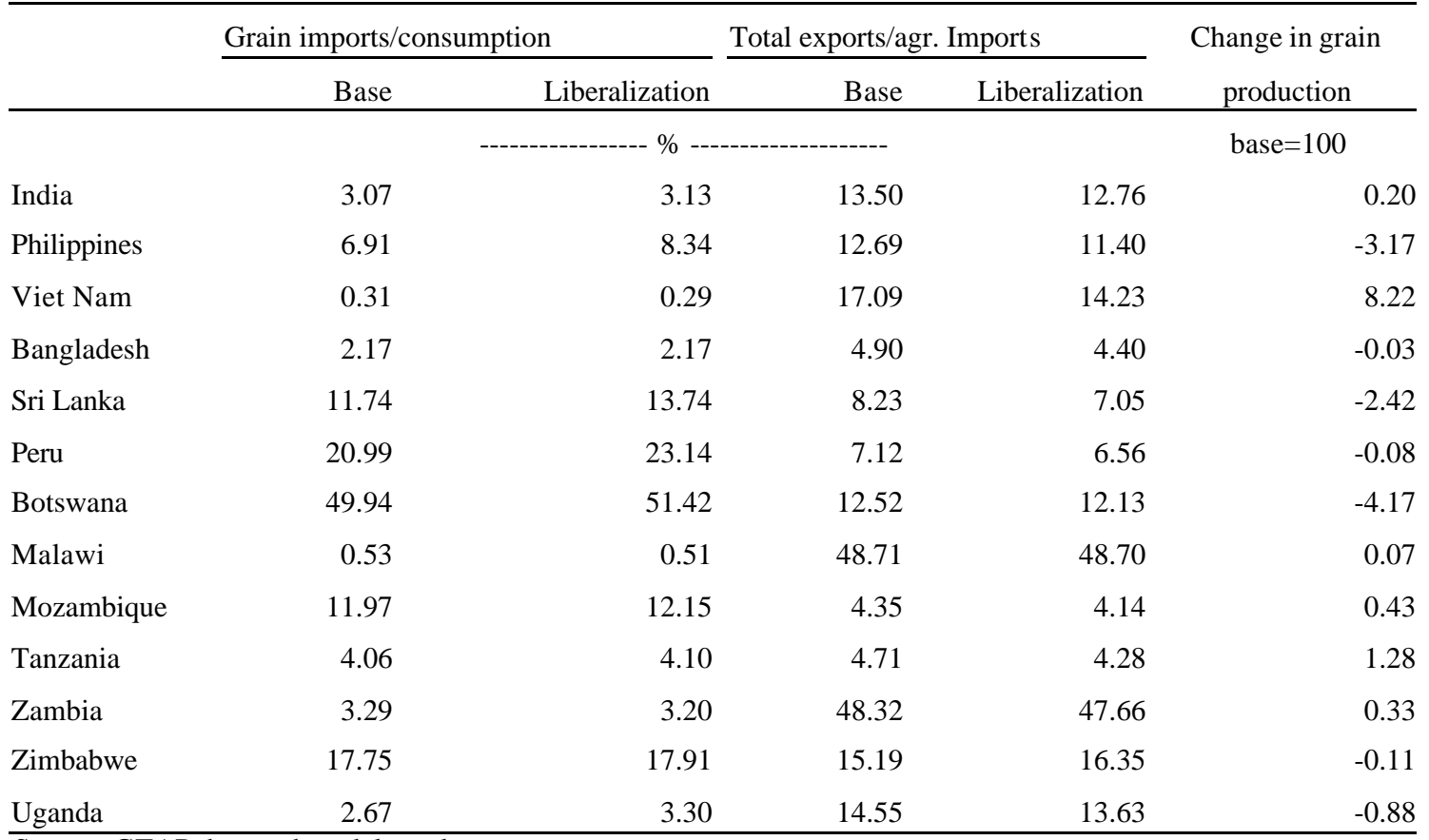

Source: GTAP data and model results.

Table 5. Dynamic Welfare Effects in the Model (comparing with the base)

\begin{tabular}{|c|c|c|c|c|c|c|c|c|c|c|c|c|c|c|}
\hline & \multicolumn{7}{|c|}{ Without TFP growth } & \multicolumn{7}{|c|}{ With TFP growth } \\
\hline & $\begin{array}{l}\text { Year } 5 \\
\text { \$billion }\end{array}$ & \multicolumn{2}{|c|}{$\begin{aligned} & \text { Year } 10 \\
\% & \text { \$billion }\end{aligned}$} & \multicolumn{2}{|c|}{$\begin{aligned} & \text { Year } 15 \\
& \% \text { \$billion } \\
&\end{aligned}$} & \multicolumn{2}{|c|}{$\begin{array}{cc} & \begin{array}{c}\text { Intertemporal } \\
\text { effect }\end{array} \\
\% & \% \\
\end{array}$} & $\begin{array}{l}\text { Year } 5 \\
\$ \text { billion }\end{array}$ & \multicolumn{2}{|c|}{$\begin{array}{r}\text { Year 10 } \\
\% \quad \text { \$billion } \\
\end{array}$} & \multicolumn{2}{|c|}{$\begin{aligned} & \text { Year } 15 \\
& \% \text { \$billion } \\
&\end{aligned}$} & \multicolumn{2}{|c|}{$\begin{array}{c}\text { Intertemporal } \\
\text { effect } \\
\% \\
\end{array}$} \\
\hline World & 15.9 & 0.1 & 30.2 & 0.1 & 36.3 & 0.2 & & 27.2 & 0.1 & 47.0 & 0.2 & 56.4 & 0.2 & \\
\hline Developed country group & 14.7 & 0.1 & 25.7 & 0.1 & 29.7 & 0.2 & & 17.0 & 0.1 & 29.6 & 0.2 & 35.1 & 0.2 & \\
\hline Japan and Korea & -1.4 & 0.0 & 3.9 & 0.1 & 5.1 & 0.2 & 0.0 & -0.9 & 0.0 & 4.7 & 0.2 & 6.2 & 0.2 & 0.0 \\
\hline North America & 9.8 & 0.1 & 11.8 & 0.2 & 13.0 & 0.2 & 0.1 & 10.3 & 0.2 & 12.9 & 0.2 & 14.7 & 0.2 & 0.1 \\
\hline European Union and EEFT & 3.1 & 0.1 & 6.7 & 0.1 & 8.2 & 0.1 & 0.0 & 4.2 & 0.1 & 8.6 & 0.1 & 10.8 & 0.2 & 0.0 \\
\hline $\begin{array}{l}\text { Developing country } \\
\text { group }\end{array}$ & 1.3 & 0.0 & 4.5 & 0.1 & 6.5 & 0.1 & & 10.2 & 0.2 & 17.4 & 0.3 & 21.3 & 0.4 & \\
\hline China & 1.2 & 0.2 & 1.7 & 0.3 & 1.8 & 0.3 & 0.1 & 1.5 & 0.2 & 2.0 & 0.3 & 2.2 & 0.4 & 0.1 \\
\hline Other Asian countries & -0.7 & -0.1 & 0.5 & 0.1 & 0.9 & 0.1 & 0.0 & 2.1 & 0.2 & 4.5 & 0.4 & 5.1 & 0.5 & 0.1 \\
\hline Mexico & -0.4 & -0.1 & -0.2 & -0.1 & 0.1 & 0.0 & 0.0 & 0.5 & 0.2 & 1.0 & 0.3 & 1.6 & 0.5 & 0.1 \\
\hline Latin America & 3.9 & 0.3 & 4.3 & 0.3 & 4.7 & 0.4 & 0.2 & 4.6 & 0.4 & 5.4 & 0.4 & 6.1 & 0.5 & 0.2 \\
\hline South African countries & 0.2 & 0.1 & 0.3 & 0.1 & 0.5 & 0.2 & 0.1 & 0.4 & 0.1 & 0.6 & 0.2 & 0.8 & 0.3 & 0.1 \\
\hline Rest of the world & -3.0 & -0.2 & -2.1 & -0.1 & -1.5 & -0.1 & -0.2 & 1.1 & 0.1 & 4.0 & 0.3 & 5.4 & 0.3 & 0.0 \\
\hline
\end{tabular}

Source: Model results. 


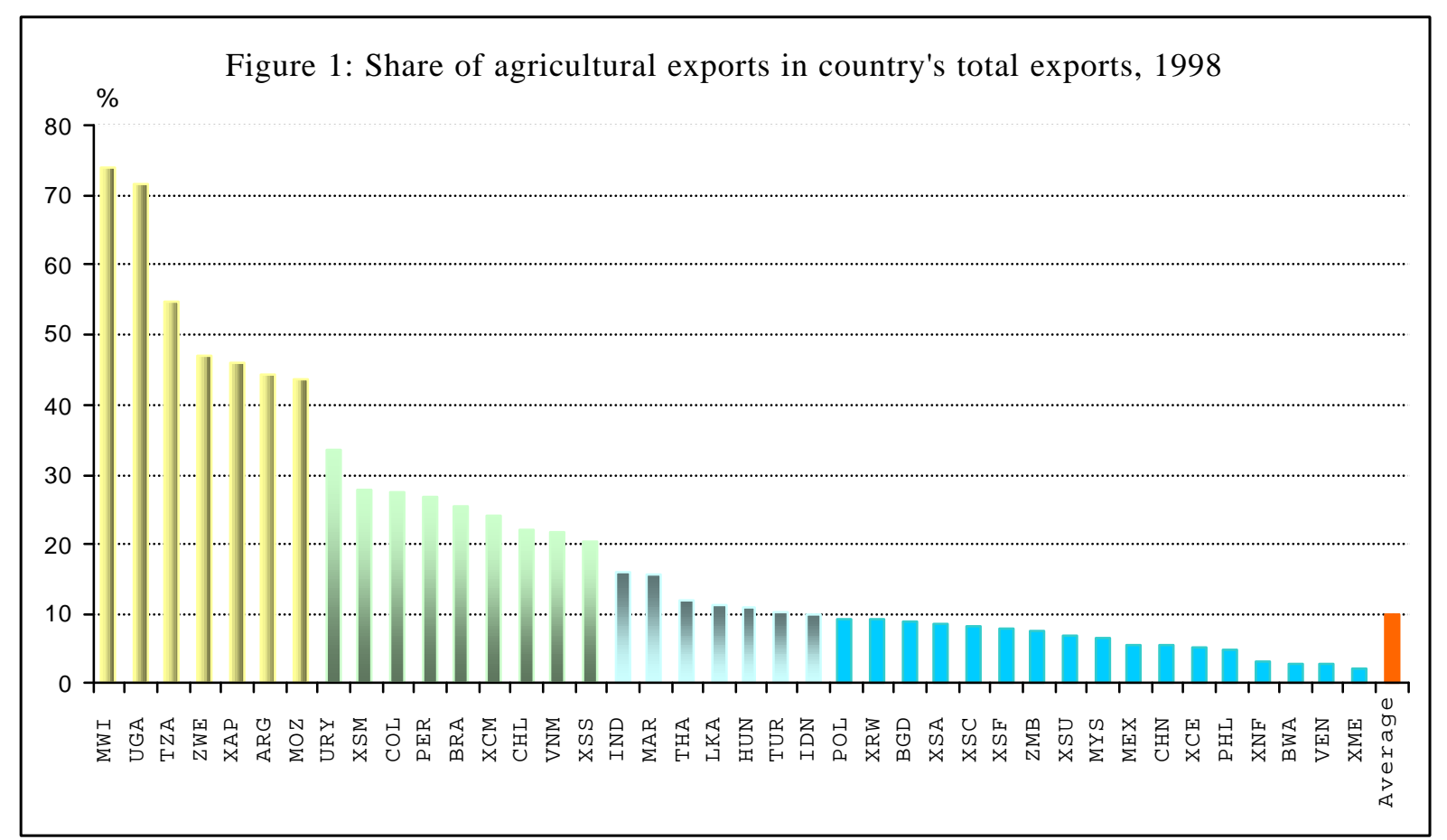

Source: GTAP data.



Source: GTAP data. 


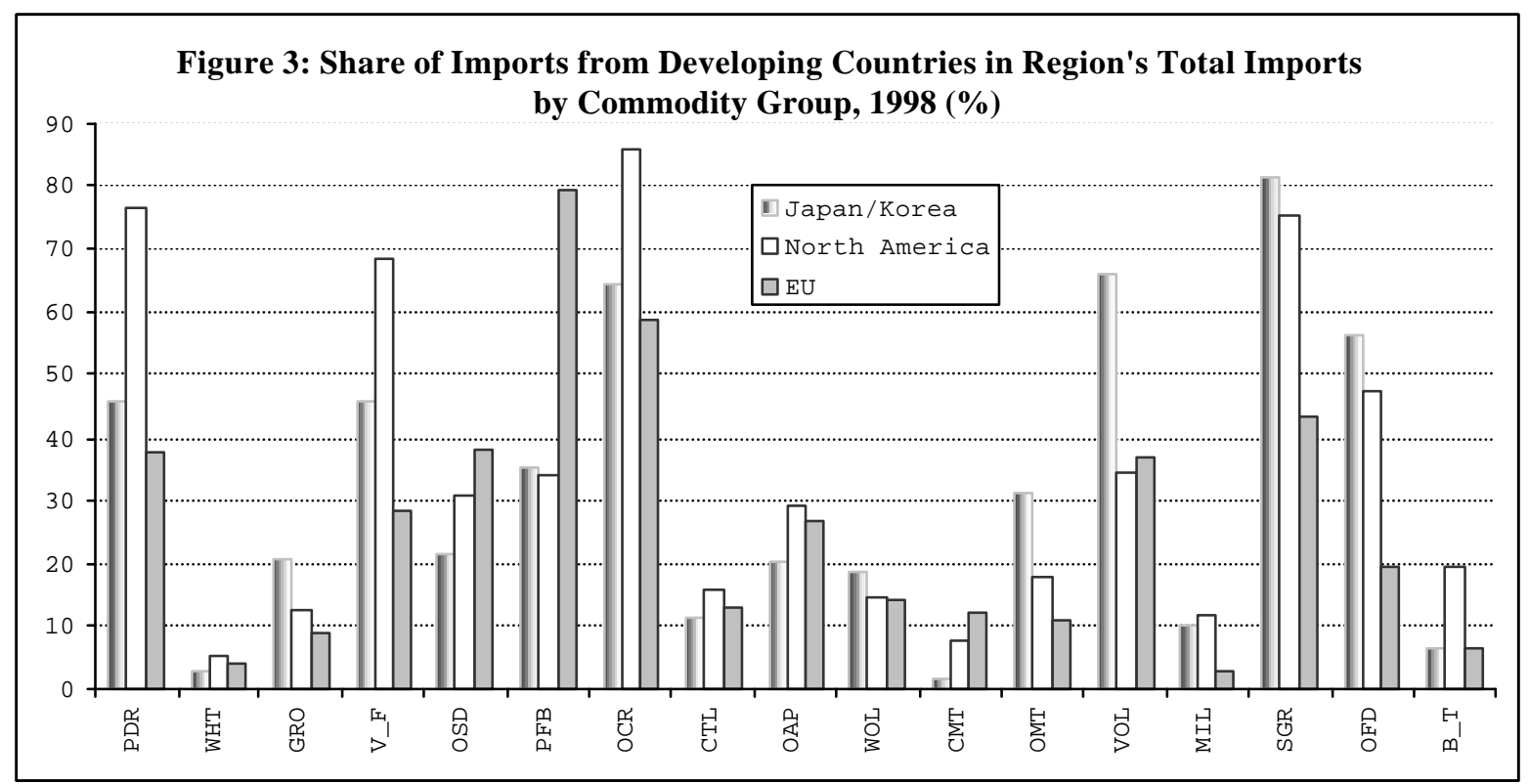

Source: GTAP data.

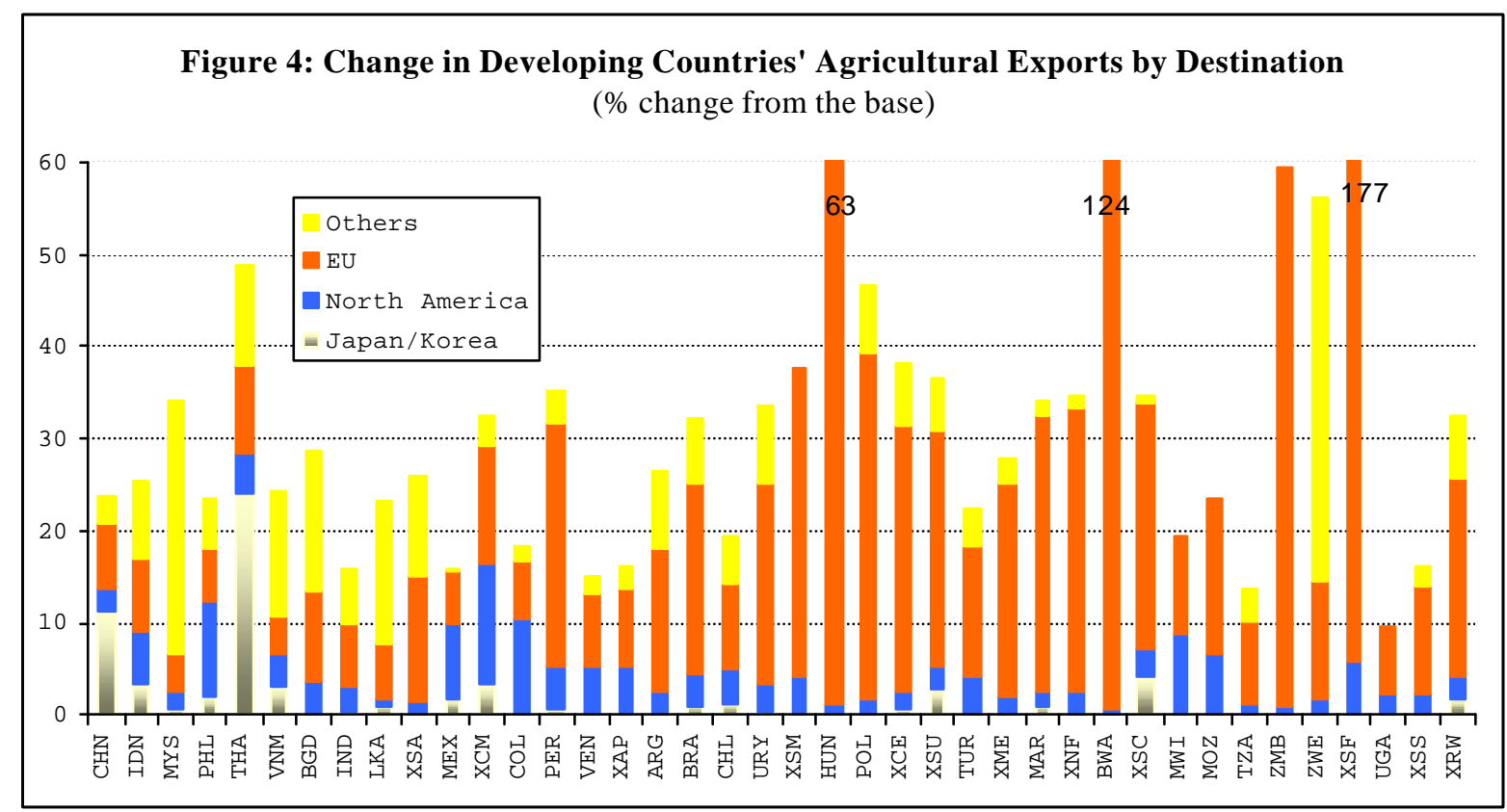

The height of bar indicates the change in total agricultural exports.

Source: Model results. 


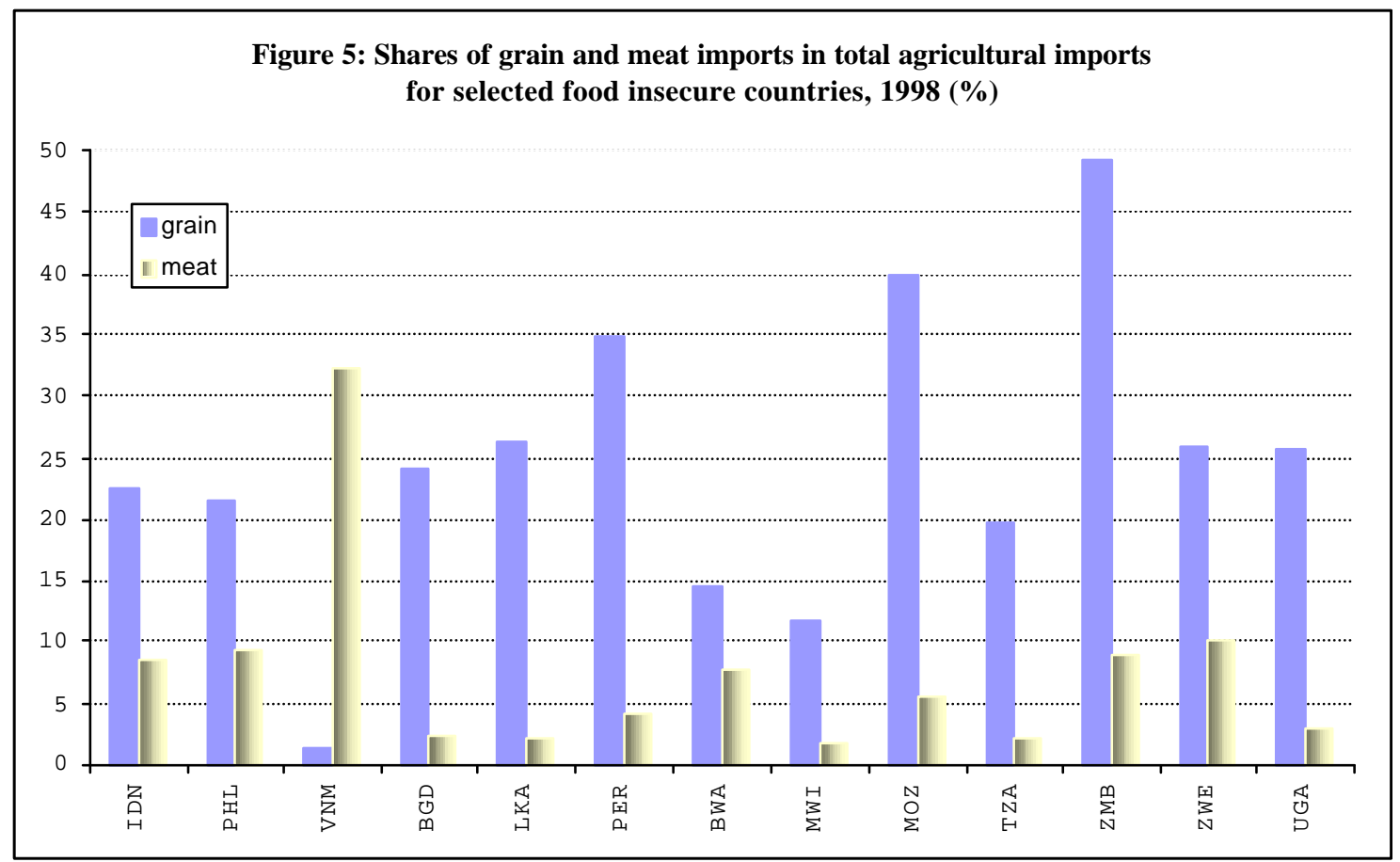

Source: GTAP data. 


\section{List of Discussion Papers}

No. 40 - $\quad$ "Parameter Estimation for a Computable General Equilibrium Model: A Maximum Entropy Approach" by Channing Arndt, Sherman Robinson and Finn Tarp (February 1999)

No. 41 - "Trade Liberalization and Complementary Domestic Policies: A Rural-Urban General Equilibrium Analysis of Morocco" by Hans Löfgren, Moataz El-Said and Sherman Robinson (April 1999)

No. 42 - $\quad$ "Alternative Industrial Development Paths for Indonesia: SAM and CGE Analysis" by Romeo M. Bautista, Sherman Robinson and Moataz El-Said (May 1999)

No. 43* - "Marketing Margins and Agricultural Technology in Mozambique" by Channing Arndt, Henning Tarp Jensen, Sherman Robinson and Finn Tarp (July 1999)

No. 44 - $\quad$ "The Distributional Impact of Macroeconomic Shocks in Mexico: Threshold Effects in a Multi-Region CGE Model" by Rebecca Lee Harris (July 1999)

No. 45 - "Economic Growth and Poverty Reduction in Indochina: Lessons From East Asia" by Romeo M. Bautista (September 1999)

No. 46* - "After the Negotiations: Assessing the Impact of Free Trade Agreements in Southern Africa" by Jeffrey D. Lewis, Sherman Robinson and Karen Thierfelder (September 1999)

No. 47* - "Impediments to Agricultural Growth in Zambia" by Rainer Wichern, Ulrich Hausner and Dennis K. Chiwele (September 1999)

No. 48 - $\quad$ "A General Equilibrium Analysis of Alternative Scenarios for Food Subsidy Reform in Egypt" by Hans Lofgren and Moataz El-Said (September 1999)

No. 49*_ “A 1995 Social Accounting Matrix for Zambia” by Ulrich Hausner (September 1999)

No. 50 - " "Reconciling Household Surveys and National Accounts Data Using a Cross Entropy Estimation Method" by Anne-Sophie Robilliard and Sherman Robinson (November 1999) 
No. 51 - "Agriculture-Based Development: A SAM Perspective on Central Viet Nam" by Romeo M. Bautista (January 2000)

No. 52 - "Structural Adjustment, Agriculture, and Deforestation in the Sumatera Regional Economy" by Nu Nu San, Hans Löfgren and Sherman Robinson (March 2000)

No. 53 - "Empirical Models, Rules, and Optimization: Turning Positive Economics on its Head" by Andrea Cattaneo and Sherman Robinson (April 2000)

No. 54 - "Small Countries and the Case for Regionalism vs. Multilateralism" by Mary E. Burfisher, Sherman Robinson and Karen Thierfelder (May 2000)

No. 55 - "Genetic Engineering and Trade: Panacea or Dilemma for Developing Countries" by Chantal Pohl Nielsen, Sherman Robinson and Karen Thierfelder (May 2000)

No. 56 - "An International, Multi-region General Equilibrium Model of Agricultural Trade Liberalization in the South Mediterranean NIC's, Turkey, and the European Union" by Ali Bayar, Xinshen Diao and A. Erinc Yeldan (May 2000)

No. 57* - "Macroeconomic and Agricultural Reforms in Zimbabwe: Policy Complementarities Toward Equitable Growth" by Romeo M. Bautista and Marcelle Thomas (June 2000)

No. 58 - "Updating and Estimating a Social Accounting Matrix Using Cross Entropy Methods" by Sherman Robinson, Andrea Cattaneo and Moataz El-Said (August 2000)

No. 59 - "Food Security and Trade Negotiations in the World Trade Organization : A Cluster Analysis of Country Groups " by Eugenio Diaz-Bonilla, Marcelle Thomas, Andrea Cattaneo and Sherman Robinson (November 2000)

No. 60* - "Why the Poor Care About Partial Versus General Equilibrium Effects Part 1: Methodology and Country Case" by Peter Wobst (November 2000)

No. 61- "Growth, Distribution and Poverty in Madagascar : Learning from a Microsimulation Model in a General Equilibrium Framework" by Denis Cogneau and Anne-Sophie Robilliard (November 2000) 
No. 62- "Farmland Holdings, Crop Planting Structure and Input Usage: An Analysis of China's Agricultural Census" by Xinshen Diao, Yi Zhang and Agapi

Somwaru (November 2000)

No. 63 - "Rural Labor Migration, Characteristics, and Employment Patterns: A Study Based on China's Agricultural Census" by Francis Tuan, Agapi Somwaru and Xinshen Diao (November 2000)

No. 64 - "GAMS Code for Estimating a Social Accounting Matrix (SAM) Using Cross Entropy (CE) Methods" by Sherman Robinson and Moataz El-Said (December 2000)

No. 65 - “A Computable General Equilibrium Analysis of Mexico’s Agricultural Policy Reforms" by Rebecca Lee Harris (January 2001)

No. 66 - "Distribution and Growth in Latin America in an Era of Structural Reform" by Samuel A. Morley (January 2001)

No. 67 - "What has Happened to Growth in Latin America" by Samuel A. Morley (January 2001)

No. 68 - "China's WTO Accession: Conflicts with Domestic Agricultural Policies and Institutions" by Hunter Colby, Xinshen Diao and Francis Tuan (January 2001)

No. 69 - "A 1998 Social Accounting Matrix for Malawi” by Osten Chulu and Peter Wobst (February 2001)

No. 70 - “A CGE Model for Malawi: Technical Documentation” by Hans Löfgren (February 2001)

No. 71 - "External Shocks and Domestic Poverty Alleviation: Simulations with a CGE Model of Malawi" by Hans Löfgren with Osten Chulu, Osky Sichinga, Franklin Simtowe, Hardwick Tchale, Ralph Tseka and Peter Wobst (February 2001)

No. 72 - "Less Poverty in Egypt? Explorations of Alternative Pasts with Lessons for the Future" Hans Löfgren (February 2001)

No. 73 - "Macro Policies and the Food Sector in Bangladesh: A General Equilibrium Analysis" Marzia Fontana, Peter Wobst and Paul Dorosh (February 2001)

No. 74 - "A 1993-94 Social Accounting Matrix with Gender Features for Bangladesh" Marzia Fontana and Peter Wobst, (April 2001) 
No. 75 - “A Standard Computable General Equilibrium (CGE) Model in” Hans Löfgren, Rebecca Lee Harris and Sherman Robinson (April 2001)

No. 76 - " A Regional General Equilibrium Analysis of the Welfare Impact of Cash Transfers: An Analysis of Progresa in Mexico" David P. Coady and Rebecca Lee Harris (June 2001)

No. 77 - "Genetically Modified Foods, Trade, and Developing Countries" Chantal Pohl Nielsen, Karen Thierfelder and Sherman Robinson (August 2001)

No. 78 - "The Impact of Alternative Development Strategies on Growth and Distribution: Simulations with a Dynamic Model for Egypt" Moataz El-Said, Hans Löfgren and Sherman Robinson (September 2001)

No. 79- "Impact of MFA Phase-Out on the World Economy an Intertemporal, Global General Equilibrium Analysis" Xinshen Diao and Agapi Somwaru (October 2001)

No. 80* - "Free Trade Agreements and the SADC Economies" Jeffrey D. Lewis, Sherman Robinson and Karen Thierfelder (November 2001)

No. 81- "WTO, and developing countries. An issues paper" by Eugenio DíazBonilla, Sherman Robinson, Marcelle Thomas and Yuki Yanoma (November 2001)

No. 82 - "WTO, food security and developing countries" by Eugenio DíazBonilla, Marcelle Thoms and Sherman Robinson (November 2001)

No. 83 - "Economy-wide effects of El Niño/Southern Oscillation ENSO in Mexico and the role of improved forecasting and technological change" by Rebecca Lee Harris and Sherman Robinson (November 2001)

No. 84 - "Land reform in Zimbabwe: Farm-level effects and cost-benefit analysis" by Anne-Sophie Robilliard, Crispen Sukume, Yuki Yanoma and Hans Löfgren (December 2001)

No. 85 - "Developing country interest in agricultural reforms under the World Trade Organization" by Xinshen Diao, Terry Roe and Agapi somwaru (January 2002)

TMD Discussion Papers marked with an '*' are MERRISA-related. Copies can be obtained by calling Maria Cohan at 202-862-5627 or e-mail: m.cohan@cgiar.org 